\title{
LARGE-SCALE EVOLUTIONARY PATTERNS OF HOST PLANT ASSOCIATIONS IN THE LEPIDOPTERA
}

\author{
Steph B. J. Menken, ${ }^{1,2}$ Jacobus J. Boomsma, ${ }^{3,4}$ and Erik J. van Nieukerken ${ }^{5,6}$ \\ ${ }^{1}$ Institute for Biodiversity and Ecosystem Dynamics, Section Evolutionary Biology, University of Amsterdam, Kruislaan 318, \\ 1098 SM Amsterdam, The Netherlands \\ 2E-mail: S.B.J.Menken@uva.nl \\ ${ }^{3}$ Department of Biology, University of Copenhagen, Universitetsparken 15, 2100 Copenhagen, Denmark \\ ${ }^{4}$ E-mail: JJBoomsma@bio.ku.dk \\ ${ }^{5}$ National Museum of Natural History Naturalis, P.O. Box 9517, 2300 RA Leiden, The Netherlands \\ ${ }^{6}$ E-mail: Nieukerken@naturalis.nl
}

Received November 19, 2007

Accepted October 13, 2009

\begin{abstract}
We characterized evolutionary patterns of host plant use across about 2500 species of British Lepidoptera, using character optimization and independent phylogenetic contrasts among 95 operational taxa, and evaluated the extent to which caterpillars are monophagous, use woody host plants, and feed concealed. We also analyzed the use of different Angiosperm superorders and related these associations to other key variables. The Nepticulidae, Pterophoridae, and Gracillariidae allowed explicit comparisons between the British fauna and the Lepidoptera worldwide, which indicated that our broad categorizations for Britain are accurate predictors for the global fauna. The first (lower glossatan) radiation of the Lepidoptera started with monophagous, internal feeding on woody Eurosids I. Polyphagy on nonwoody Eurosids I evolved together with the ability to feed externally, but did initially not produce significant radiations. Exposed feeding became associated with radiations in the lower Ditrysia and Apoditrysia and remained correlated with more polyphagy, fewer woody host plants, and increasing use of other Angiosperm superorders. The macrolepidopteran radiation has frequent reversals to monophagy on woody Eurosids $\mathrm{I}$, particularly in taxa that lost concealed feeding. We discuss the general implications of these results and address several key adaptations and constraints that have characterized the major transitions in lepidopteran life histories.
\end{abstract}

KEY WORDS: Comparative analysis, diet breadth, external feeding, Eurosids I, phytophagous insects.

The insects represent more than half of the world's known species (Grimaldi and Engel 2005) and are particularly well represented in terrestrial ecosystems, both in numbers and biomass, but the timing and drivers of their adaptive radiations are still only fragmentary understood (Tilmon 2008). The evolutionary dynamics that have led to extant biodiversity are particularly complex for the many clades that coevolved with their hosts, either as herbivores

The first two authors contributed equally.
(Price 2002) or as parasitoids (Heraty 2009). Recent comparative studies have indicated that ecological specialization, either on a single host species or on a single feeding mode, has impaired speciation rates in nematine sawflies (Nyman et al. 2006) and nymphalid butterflies (Janz et al. 2006), suggesting that resource diversity and niche complementarity are causes rather than consequences of speciation as has been suggested by theory (Ackermann and Doebeli 2004). However, ecological specialization is likely to characterize both the early evolution of clades 
and later elaborations, as periods of specialization are likely to be punctuated by episodes of host expansion (Janz et al. 2006), so that large datasets are needed to capture the dynamics of this process in a relatively complete manner (see, e.g., the meta-analysis by Winkler and Mitter [2008]). Our present study uses data spanning an entire order of phytophagous insects, addressing both the specialized origin of herbivory, its later diversifications and elaborations, and its secondary reversals to specialization in diet breath and host plant association.

With an estimated 150,000 to 200,000 described species, the Lepidoptera are one of the four major insect orders. Together with the beetle clade Phytophaga (Curculionoidea and Chrysomeloidea) (Farrell and Sequeira 2004), the Lepidoptera represent the largest radiation of phytophagous insects and express a bewildering variation of adaptations to detect, select, ingest, and digest live plant tissue. Apart from the two most basal superfamilies Micropterigoidea and Agathiphagoidea, whose larvae feed on mosses and gymnosperms, all lepidopteran superfamilies have host plant associations with Angiosperms. Independent and secondary shifts to nonflowering plants or nonplant food are few and restricted to subordinate taxa (e.g., detritiphagous larvae in several groups; fungivorous and keratin feeding larvae in the Tineidae [Davis and Robinson 1998]; carnivorous larvae in the Cosmopterigidae, Epipyropidae, Lycaenidae, and some others [Pierce 1995]). The most apparent general patterns that have emerged from comparative studies of lepidopteran host plant associations are the common occurrence of host plant specialization (e.g., Scott 1986; Janzen 1988; Thompson 1994) and the widespread phylogenetic conservatism in host plant use, that is, the tendency of radiating clades to remain associated with the same genus or family of host plants (e.g., Ehrlich and Raven 1964; Menken 1996; Janz and Nylin 1998; Winkler and Mitter 2008).

Many aspects of host plant specialization are associated with the mode of larval feeding. Internal feeders such as leaf miners and gall formers, live concealed within plant structures for most of their life. Compared to exposed, externally feeding larvae, such intimate physical and functional relationships with host plants should predictably lead to a higher degree of specificity (Mattson et al. 1988). Indeed, Gaston and Reavey (1989) and Gaston et al. (1992) found that British microlepidopteran genera with a large number of species with concealed feeding have more host plant specialists than genera with externally feeding larvae. Avoidance of high costs of (mostly chemical) information processing and advantages of habitat predictability (Nosil 2002 and references therein) may both select for specialization of resource use, but it is unclear whether such developments toward narrow diets represent advanced evolutionary dead-ends or, at least in some cases, sources of new radiation (e.g., Holloway and Hebert 1979; Janz and Nylin 1998; Nosil and Mooers 2005).
There is now ample evidence that conservatism in host plant use and/or feeding mode does not imply cocladogenesis (Jermy 1984, 1993; Janz and Nylin 1998; Braby and Trueman 2006; Lopez-Vaamonde et al. 2006). Within host plant genera, the colonization of new hosts by phytophagous insects has a large element of phylogenetic randomness. Moreover, rare successful colonization across the boundaries of higher host plant taxa may induce considerable adaptive radiations. This implies that strict coevolution between phytophagous insects and their host plants is rare (Ehrlich and Raven 1964; Farrell and Mitter 1998; Pellmyr 2003). A major factor determining the success of host shifts is similarity in chemical profiles of secondary plant compounds, with diet breadth being determined by a "balance" between sensitivity to plant attractants and insensitivity to deterrents. Herbivorous insects are thus most likely to shift to host plants that are phytochemically related, which is only partially correlated with common ancestry (Brower and Brower 1964; Menken and Roessingh 1998; Mao et al. 2006; Wheat et al. 2007). Also ecological similarity in, for example, plant growth form (Powell 1980; Janz and Nylin 1998) and ecological opportunity (sympatry) may be of decisive importance for host-plant shifts and these factors also tend to be independent of phylogenetic relatedness.

The depth of knowledge of the British entomofauna is unrivalled worldwide. Detailed information on host plant associations and other larval life-history traits is available for the entire British Lepidoptera fauna of more than 2500 species (Emmet 1991). We have used these data to investigate whether evolutionary footprints of host plant associations can be detected in a large-scale analysis encompassing the phylogenetic relationships of all British moths and butterflies. To avoid measuring merely idiosyncratic species-specific patterns of host plant use, we compared genus, tribe, subfamily, or family-level taxa (depending on species number) of British Lepidoptera with host plant use at the level of Angiosperm (super)orders. The major objectives of our comparative study were to: (1) Quantitatively test the hypothesis that host plant use of early lepidopteran clades was characterized by the same suite of traits that are still found in the extant species of the most speciose basal family Nepticulidae, that is, concealed larval feeding, a narrow breadth of diet (monophagy), and woody Angiosperm (mostly Eurosids I) host plants, (2) Evaluate whether evolution of host plant use has followed consistent patterns across lineages during and after major transitions in larval life history, and whether the degree of adaptive radiation in the major subdivisions of the Lepidoptera is associated with these patterns, and (3) Provide an evaluation of the likelihood that our results are generally valid for the Lepidoptera worldwide. Our coarse-grained approach permitted such evaluation for three families (Nepticulidae, Gracillariidae, and Pterophoridae), in spite of the fact that global insect faunas, in particular tropical ones, are poorly known relative to the British fauna. Objective 1 allowed us to evaluate 
whether constraints due to specialization are likely to have affected the early diversification of the Lepidoptera. Objective 2 provided an opportunity to evaluate the extent to which cycles of host expansion and specialization (cf., Janz et al. 2006) primarily involve diet breadth, or also host plant phylogenetic identity and apparency (Feeney 1976), and larval feeding mode.

\section{Materials and Methods SOURCES OF INFORMATION}

We used the following sources to characterize and quantify patterns of host plant use and the phylogenetic relationships of lepidopteran taxa:

(1) Complete species-level data on feeding habits of the British Lepidoptera (Emmet 1991).

(2) The superfamily-level phylogeny of the Lepidoptera by Kristensen and Skalski (1998) and the species classification by Karsholt and Razowski (1996), which follows the principles of the Kristensen (1998a) classification. This ordinal phylogeny is still widely accepted as the best tree for the entire order of the Lepidoptera that is currently available (e.g., the web-based projects http://leptree.net/ and http://www.tolweb.org/Lepidoptera; see also Kristensen et al. 2007). Detailed molecular phylogenies are currently being built in the LepTree project, but were insufficiently complete at the time of our analysis to provide a better alternative.

Additional lower-level phylogenetic information was obtained from Nielsen and Davis (1985) and Friedlander et al. (2000) for the Incurvarioidea, from Kyrki (1990) for the Yponomeutoidea, from Hodges (1998) for the Gelechioidea, from Solis and Mitter (1992) for the Pyralidae, from Ackery et al. (1998) and De Jong et al. (1996) for the Rhopalocera, and from Mitchell et al. (2000) for the Noctuoidea. The latter study used several methods that gave partly different results. Of these, we selected a simplified noctuid cladogram, in which the Nolidae are the sistergroup to a polytomous clade consisting of the noctuid subfamilies with quadrifine hindwing venation: Catocalinae, Hypeninae, and Hermiinae, plus the Arctiidae + Lymantriidae. In this tree, the Acontiinae are sister group to a polytomy of the remaining noctuid subfamilies, which have a trifine hindwing venation, with only the Noctuinae + Hadeninae forming a clade (some of these clades do not appear in Fig. 1 because they were excluded from analysis - see below). In a more recent paper these general findings were largely supported (Mitchell et al. 2006) and proposals were made to raise quadrifine subfamilies to full family status. However, Lafontaine and Fibiger (2006) proposed a single large family Noctuidae, including Arctiidae and Lymantriidae. For other lepidopteran taxa we used information from Kristensen (1998a) to reconstruct phylogenies. If no phylogeny was available (Gracillariidae, Tortrici- dae, Crambidae, and Geometridae), we used the classification in Linnaean ranks and defined all nested levels as polytomies.

(3) Host plant classifications followed the Angiosperm Phylogeny Group classification (Bremer et al. 2003a), with host plant phylogeny being based on Soltis et al. (2000).

(4) Information about the proportional representation of Eurosid I families in the world flora originated from Bremer et al. (2003b) and from Stace (1997) for the flora of Great Britain.

(5) Information about the worldwide patterns of host plant use came from an unpublished database by Van Nieukerken for the Nepticulidae (a preliminary analysis was published in Van Nieukerken 1986), from Lopez-Vaamonde et al. (2003) and De Prins and De Prins (2005) for the Gracillariidae, and from Gielis (2003) for the Pterophoridae.

\section{STRUCTURING THE DATASET}

To obtain reasonable compromises between having a fairly large number of independent contrasts while avoiding that lepidopteran taxa became so poor in species that proportions would be too much affected by sampling error, we adopted a number of practical datastructuring measures. First, taxa with fewer than five species with relevant data were excluded from the analyses (see Appendix for a complete list). Second, available phylogenies were usually not resolved below the family level, which implied that subfamilies within families and genera within subfamilies had to be treated as polytomies. We have only adopted these polytomial subclassifications when: (1) The (sub)families had many species, so that subordinate taxa would not end up with sample sizes $<5$, and (2) The total number of species lost per (sub)family did not exceed $20 \%$. For example, we split the Nepticulidae into the three largest genera (Stigmella, Trifurcula, and Ectoedemia) as this provided an extra independent contrast and made us loose less than $4 \%$ of the species records in the small genera Bohemannia and Enteucha that now became excluded from the analysis (see Appendix).

The final operational phylogeny of the Lepidoptera that we obtained to calculate independent contrasts consisted of 95 clades: genera, tribes, subfamilies, and families (Fig. 1, Appendix). These clades were grouped for summary purposes in larger evolutionary "grades"; 10 of them as lower Glossata, 25 as lower Ditrysia, 30 as lower Apoditrysia, and 30 as Macrolepidoptera.

\section{CATEGORIZING TRAITS ASSOCIATED WITH HOST PLANT USE}

In our larval feeding dataset, we focused on the following four traits and registered their proportional representation per taxon:

(1) Feeding mode: The proportion of species with internal (concealed) larval feeding (i.e., mining, galling, boring, underground feeding, spinning, and feeding from a portable case) versus species with exposed larval feeding (i.e., living in a loose 


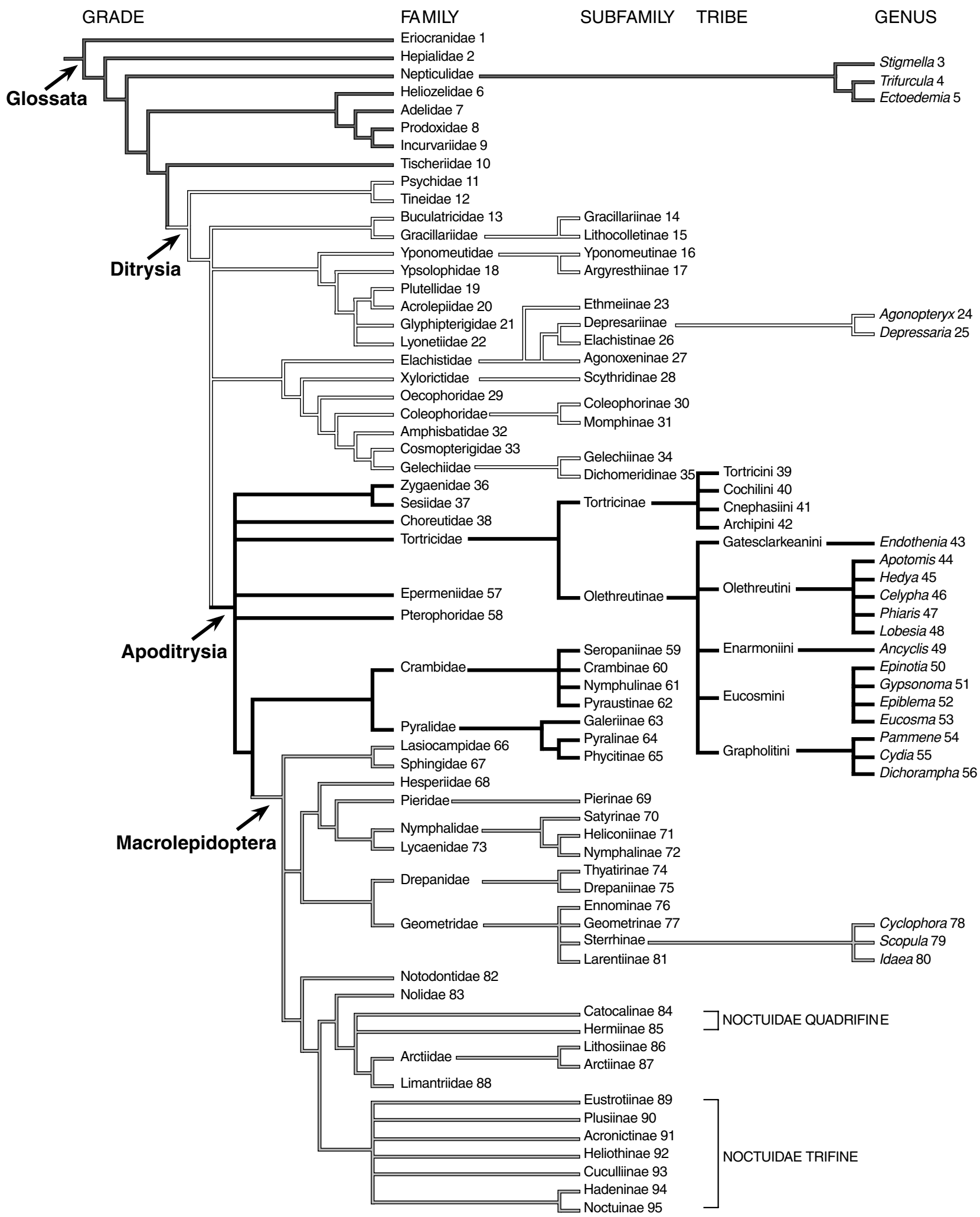

Figure 1. The currently most widely accepted phylogenetic relationships, based on Kristensen (1998a) and various other sources (see Materials and Methods), among the 95 lepidopteran taxa that were used in the comparative analyses. Major grades are indicated with arrows toward the left: lower Glossata (rank number 1-10; dark gray branches), lower Ditrysia (11-35; white branches), lower Apodytrisia (36-65; black branches), and Macrolepidoptera (66-95; light gray branches). Noctuidae quadrifine refers to subfamilies with a quadrifine hindwing venation (in which MA2 is a strong vein, arising close to MP1). Trifine refers to subfamilies with a trifine hindwing venation (in which MA2 arises nearer to MA1 than to MP1 and may be reduced or absent) (see Kitching and Rawlins [1998]). 
web, in a tube of silk that the larva occasionally leaves to feed, and external feeding).

(2) Woodiness of host plants: The proportion of species whose larvae use woody host plants (almost always Angiosperms) versus species using other food (in the large majority of cases nonwoody dicotyledonous herbs and monocots, but also the rare records of feeding on dead plant material, fungi, keratin, and other organic matter).

(3) Diet breadth: The proportion of species whose larvae are generalists (oligophagous and polyphagous species, feeding on plant species from at least different genera-see definitions below) versus species whose larvae are specialists (monophagous and strictly monophagous species, feeding on plants within a single genus-see definitions below).

(4) Share of Eurosid I host plants: The proportion of species whose larvae feed on host plants belonging to the Angiosperm superorder Eurosids I (including the Celastrales, Cucurbitales, Fabales, Fagales, Malpighiales, Oxalidales, Rosales, and Zygophyllales) versus species with larvae that feed on any other food (other higher plants, fungi etc.). This categorization was inspired by the observation that $89.5 \%$ of the British species of the largest lower glossatan family Nepticulidae use Eurosid I host plants (Emmet 1991). As this figure was known to be also high in most other nepticulid faunas (Van Nieukerken 1986), we considered the proportional representation of this higher host plant taxon in more advanced lepidopteran clades to be particularly informative for tracking phylogenetic trends toward more diverse host plant use. The general importance of Eurosids I as a key clade for the early evolution of several taxa of phytophagous insects and mites has recently been highlighted by Ward et al. (2003). The Eurosids I are a clade within the larger Rosids clade. We use the term "other Rosids" for Rosid families that do not belong to the Eurosid I clade (Bremer et al. 2003a).

To reconstruct ancestral states and elucidate changes at internal nodes, the four key traits of our analysis were encoded as discrete character states: larval feeding mode (internal 0, external 1 ), woodiness of host plant (woody 0 , nonwoody 1 ), larval diet breadth (specialist 0 , generalist 1), and share of Eurosid I host plants (Eurosids I 0, nonEurosids I 1). This allowed us to map these traits on the phylogenetic tree of Figure 1 using MacClade (Maddison and Maddison 2003). The original proportions were thus converted into binary states with a cut-off at 0.5 , for example, feeding mode was encoded as 0 (internal feeding) when the proportion of concealed feeding in a taxon exceeded $50 \%$.

Relationships between the four key variables were investigated (where appropriate after arcsine transformation) both by linear regression and by comparative analysis of independent contrasts (CAIC) (Purvis and Rambaut 1995), a method that corrects for confounding effects of phylogenetic coancestry. Diet breadth and share of Eurosid I host plants were treated as dependent (evolutionary response) variables, whereas woodiness and feeding mode were treated as predictor variables in either single or multiple regressions (regressions through the origin in CAIC). Analyses were run for the lower Glossata (10 taxa), the lower Ditrysia ( $n=$ $25)$, the Apoditrysia (including the Macrolepidoptera; $n=60$ ), and the entire dataset $(n=95)$. A second set of analyses added cumulative results for the lower Glossata + lower Ditrysia $(n=$ 35 ) and the lower Glossata + lower Ditrysia + lower Apoditrysia $(n=65)$.

For the comparative analysis of host plant data in Britain and the rest of the world, we used the relatively complete datasets for Nepticulidae, Gracillariidae, and Pterophoridae, families belonging to the lower Glossata, lower Ditrysia, and lower Apoditrysia, respectively. Comparisons could be made for woodiness (categories distinguished: gymnosperms, monocots, woody dicots, and herbaceous dicots), diet breadth (categories distinguished: strictly monophagous-feeding on one plant species, monophagousfeeding on several plant species within a genus, oligophagousfeeding on species from one or two related plant families, and polyphagous-feeding on species from different plant families), and share of Eurosids I. However, variation in feeding mode could only be compared for the Pterophoridae, as all larvae of the other two families have internal (concealed) feeding (mostly as leaf miners). Because the British fauna does not have endemic species, the British species were also part of the World dataset, but feeding habits were occasionally different or broader outside Britain. For each of the three families, we tested the null hypothesis of no difference in the proportional representation of larval feeding categories between Britain and the rest of the world with twotailed Fisher's exact tests or G-tests for goodness of fit (Sokal and Rohlf 1995). Although a comparable worldwide dataset for the Macrolepidoptera was not available for explicit testing, we believe that our three other datasets allowed a reasonable impression of how representative the patterns of host plant use in the British fauna are likely to be for the Lepidoptera worldwide.

\section{Results}

\section{PHYLOGENETIC PATTERNS OF LARVAL HOST PLANT USE IN BRITISH LEPIDOPTERA}

The total dataset of 95 records (Appendix) produced an array of regression results representing trends of variable significance and explanatory power $\left(r^{2}\right)$ (Table 1). In general, the normal and CAIC regressions produced very similar results, so that we felt justified to use the easier interpretable normal regressions in the scatter plots to illustrate the main results. A number of violations of the evolutionary and statistical assumptions listed in the CAIC manual occurred, but mostly in the predictor variables and they were rarely highly significant (Table 1). As the proportion of explained variance in normal and CAIC regressions remained 
Table 1. The normal and CAIC regression analyses for lower Glossata, lower Ditrysia, Apoditrysia, and the total dataset. Variable abbreviations: exp, proportion exposed feeding; woo, proportion woody host plants; gen, proportion generalist feeding; Eur, proportion Eurosids I host plants. The proportion of explained variance $\left(r^{2}\right)$ is given for both regressions, but statistics $(F)$ and significances $(P)$ are based on CAIC regressions through the origin. CAIC warnings for violations of evolutionary assumptions are given as $\wedge(P<0.05), \wedge \wedge$ $(P<0.01)$, and ${ }^{\wedge \wedge \wedge}(P<0.001)$, and as ${ }^{*}(P<0.05),{ }^{* *}(P<0.01)$, and ${ }^{* * *}(P<0.001)$ for violations of statistical assumptions. Analyses were run both for untransformed and arcsine square root transformed proportions. The $F$ and $P$ values refer to the results based on untransformed data, unless arcsine transformed data gave fewer or smaller violations of assumptions (in those cases an (a) behind the CAIC results indicates that arcsine transformed data were used).

\begin{tabular}{|c|c|c|c|c|c|c|c|c|c|c|c|}
\hline \multicolumn{6}{|c|}{ Lower Glossata $(n=10)$} & \multicolumn{6}{|c|}{ Lower Ditrysia $(n=25)$} \\
\hline & $x$ & $y$ & & $r^{2}$ & $F(P)$ & & $x$ & $y$ & & $r^{2}$ & $F(P)$ \\
\hline Normal & $\exp$ & gen & $y=0.78 x+0.15$ & 0.65 & & Normal & $\exp$ & gen & $y=0.31 x+0.25$ & 0.23 & \\
\hline CAIC & $\wedge \wedge$ & & $y=0.83 x$ & 0.67 & $16.14(0.0039)$ & CAIC & & & $y=0.23 x$ & 0.19 & $4.97(0.0368)$ \\
\hline Normal & $\exp$ & woo & $y=-0.98 x+0.88$ & 0.80 & & Normal & $\exp$ & woo & $y=-0.22 x+0.50$ & 0.06 & \\
\hline CAIC & $\wedge \wedge$ & res* & $y=-1.10 x$ & 0.85 & $46.85(0.0001)$ & CAIC & & & $y=-0.08 x$ & 0.01 & $0.29(0.5976)$ \\
\hline Normal & $\exp$ & Eur & $y=-0.82 x+0.88$ & 0.72 & & Normal & $\exp$ & Eur & $y=-0.27 x+0.53$ & 0.10 & \\
\hline CAIC & $\wedge \wedge$ & $\wedge$ & $y=-0.79 x$ & 0.68 & $17.14(0.0033)$ & CAIC & & & $y=-0.17 x$ & 0.07 & $1.53(0.2309)$ \\
\hline Normal & woo & Eur & $y=0.68 x+0.26$ & 0.60 & & Normal & woo & Eur & $y=0.77 x+0.08$ & 0.69 & \\
\hline CAIC(a) & & & $y=0.60 x$ & 0.55 & $9.79(0.0140)$ & CAIC & & & $y=0.81 x$ & 0.63 & $34.50(0.0000)$ \\
\hline Normal & woo & gen & $y=-0.61 x+0.72$ & 0.48 & & Normal & woo & gen & $y=-0.32 x+0.53$ & 0.22 & \\
\hline CAIC & & & $y=-0.63 x$ & 0.56 & $10.21(0.0127)$ & CAIC & & & $y=-0.21 x$ & 0.09 & $2.05(0.1666)$ \\
\hline Normal & gen & Eur & $y=-0.51 x+0.87$ & 0.25 & & Normal & gen & Eur & $y=-0.31 x+0.51$ & 0.05 & \\
\hline CAIC(a) & & & $y=-0.36 x$ & 0.13 & $1.21(0.3040)$ & CAIC(a) & & & $y=-0.22 x$ & 0.02 & $0.49(0.4911)$ \\
\hline \multicolumn{6}{|c|}{ Apoditrysia $(n=60)$} & \multicolumn{6}{|c|}{ All Lepidoptera $(n=95)$} \\
\hline & $x$ & $y$ & & $r^{2}$ & $F(P)$ & & $x$ & $y$ & & $r^{2}$ & $F(P)$ \\
\hline Normal & $\exp$ & gen & $y=0.32 x+0.35$ & 0.10 & & Normal & $\exp$ & gen & $y=0.42 x+0.24$ & 0.29 & \\
\hline CAIC & $\wedge \wedge \wedge * *$ & & $y=0.19 x$ & 0.04 & $1.19(0.2835)$ & CAIC(a) & $\wedge \wedge$ & & $y=0.27 x$ & 0.15 & $11.15(0.0014)$ \\
\hline Normal & $\exp$ & woo & $y=0.10 x+0.32$ & 0.01 & & Normal & $\exp$ & woo & $y=-0.19 x+0.56$ & 0.04 & \\
\hline CAIC(a) & $\wedge \wedge \wedge * *$ & & $y=0.36 x$ & 0.06 & $2.20(0.1480)$ & CAIC(a) & $\wedge \wedge$ & $\wedge$ & $y=-0.14 x$ & 0.02 & $1.16(0.2845)$ \\
\hline Normal & $\exp$ & Eur & $y=0.21 x+0.23$ & 0.03 & & Normal & $\exp$ & Eur & $y=-0.18 x+0.55$ & 0.04 & \\
\hline CAIC & $\wedge \wedge \wedge *$ & & $y=0.27 x$ & 0.05 & $1.66(0.2072)$ & CAIC(a) & $\wedge \wedge$ & & $y=-0.13 x$ & 0.02 & $1.42(0.2374)$ \\
\hline Normal & woo & Eur & $y=0.65 x+0.13$ & 0.56 & & Normal & woo & Eur & $y=0.71 x+0.12$ & 0.62 & \\
\hline CAIC & $*$ & & $y=0.72 x$ & 0.75 & $95.48(0.0000)$ & CAIC & $* *$ & & $y=0.73 x$ & 0.69 & $140.65(0.0000)$ \\
\hline Normal & woo & gen & $y=-0.13 x+0.66$ & 0.03 & & Normal & woo & gen & $y=-0.26 x+0.63$ & 0.11 & \\
\hline CAIC & $*$ & & $y=-0.09 x$ & 0.02 & $0.64(0.4303)$ & CAIC(a) & $*$ & & $y=-0.21 x$ & 0.11 & $8.23(0.0056)$ \\
\hline Normal & gen & Eur & $y=-0.29 x+0.57$ & 0.06 & & Normal & gen & Eur & $y=-0.35 x+0.61$ & 0.09 & \\
\hline CAIC & $*$ & & $y=-0.29 x$ & 0.08 & $2.73(0.1084)$ & CAIC(a) & & & $y=-0.30 x$ & 0.07 & $4.50(0.0380)$ \\
\hline
\end{tabular}

very similar also in cases in which these violations occurred, we have ignored them, as we had no objective criteria to edit branch lengths (to reduce violations of evolutionary assumptions). The highly significant violations of statistical assumptions almost exclusively concerned the variable "exp" (proportion of exposed feeding), which had a relative preponderance of values of 0 and 1 .

The four diet breadth categories were about equally common in the entire dataset, that is, $21.7 \%, 26.2 \%, 24.0 \%$, and $28.1 \%$ of the species are strictly monophagous, monophagous, oligophagous, and polyphagous, respectively. However, there are clear shifts in the proportion of generalist feeding when moving from the base to the outer branches of the phylogenetic tree (Fig. 2). Most of the lower Glossatan species (58.6\%) are monophagous, with strict monophagy being the second most common diet breadth category $(21.4 \%)$ and oligophagy and particularly polyphagy being rare ( $14.5 \%$ and $5.5 \%$, respectively). The frequency of generalist feeding increases steadily through the lower Ditrysia $(30.6 \%, 31.4 \%, 26.4 \%$, and $11.6 \%$ for strictly monophagous, monophagous, oligophagous, and polyphagous feeding, respectively) and the lower Apoditrysia $(21.1 \%, 21.8 \%$, $28.6 \%$, and $28.6 \%$, respectively), but the frequency of strictly monophagous species remains as high as in the lower Glossata or even higher. The trend continues in the Macrolepidoptera, where $48.1 \%$ of the species is polyphagous and where $14.1 \%$, $18.0 \%$, and $19.8 \%$ are strictly monophagous, monophagous, and oligophagous, respectively.

The evolutionary trends in the four key variables are illustrated in Figure 3. The proportion of generalist (oligophagous 


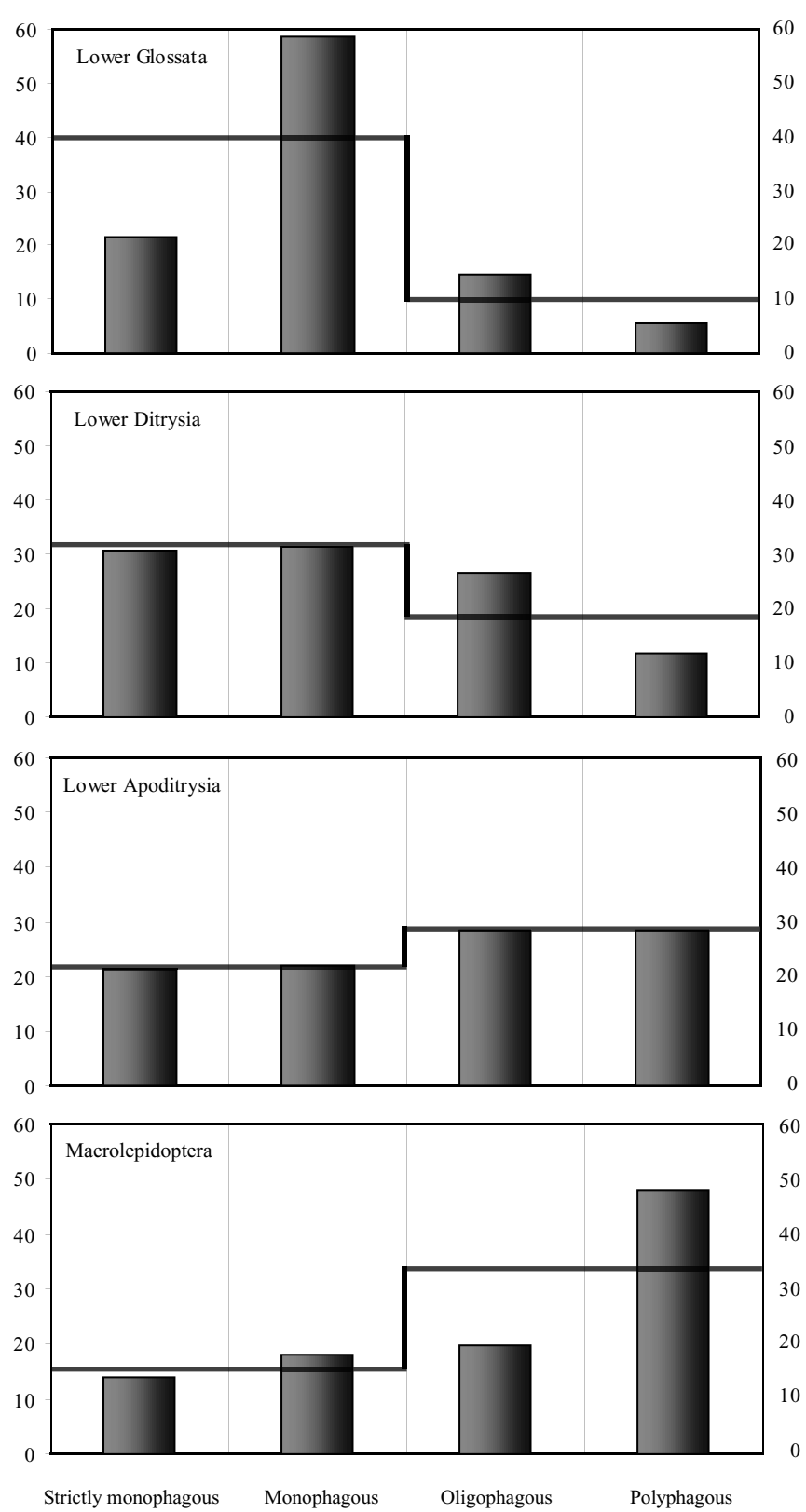

Figure 2. Mean diet breadths (\% strictly monophagous, monophagous, oligophagous, and polyphagous) across the four grades of British Lepidoptera (lower Glossata, lower Ditrysia, lower Apoditrysia, and Macrolepidoptera). Step functions indicate shifts between the former and latter two diet breadth categories as used in some of the analyses.

and polyphagous) feeding (Fig. 3C) increases with the proportion of exposed feeding (Fig. 3A) throughout the lepidopteran tree (Table 1). Correlations were significant in the lower Glossata $\left(r^{2}=0.65-0.67 ; P=0.0039\right)$, in the lower Ditrysia $\left(r^{2}=\right.$ $0.19-0.23 ; P=0.0368)$, but not anymore in the Apoditrysia $\left(r^{2}=\right.$ $0.04-0.10 ; P=0.2835$ ), where the majority of species in many taxa have returned to a specialist diet (Fig. 3C) while maintaining, with a few exceptions, their external feeding mode (Fig. 3A; Appendix). Figure 4 illustrates this pattern of decreasing slopes and increasing scatter in a cumulative manner by stepwise extending the dataset from lower Glossata $(n=10)$, via lower Glossata + lower Ditrysia $(n=10+25)$ and lower Glossata + lower Ditrysia + lower Apoditrysia $(n=10+25+30)$, to lower Glossata + lower Ditrysia + lower Apoditrysia + Macrolepidoptera $(n=$ $10+25+30+30$ ). In the latter (total) dataset the correlation is significant owing to the large sample size and the clear trends in the lower Glossata and lower Ditrysia, but the overall percentage of explained variance in the proportion of generalist feeding species is relatively low $\left(r^{2}=0.15-0.29 ; P=0.0014\right)$.

The proportion of woody host plants (Fig. 3B) and the proportion of Eurosid I host plants (Fig. 3D) both decrease sharply and significantly with the increasing proportion of exposed feeding (Fig. 3A) in the lower Glossata (respectively: $r^{2}=0.80-0.85$; $P=0.0001$ and $\left.r^{2}=0.68-0.72 ; P=0.0033\right)$ but these correlations disappear in the more derived taxa, both when considered in isolation (Table 1) and cumulatively (Fig. 5; only the relationship with Eurosids I is given as the woodiness plot is very similar). For instance, the large majority of the Nepticulidae feed internally (as leaf miners) on Eurosids I plants that are mostly trees and shrubs, but the Hepialidae and Adelidae mostly feed externally on nonwoody, non-Eurosid I host plants. It is remarkable that these correlations already disappeared in the lower Ditrysia (respectively: $r^{2}=0.01-0.06 ; P=0.5976$ and $r^{2}=0.07-0.10 ; P=$ $0.2309)$, explained even less of the variance in the Apoditrysia (respectively: $r^{2}=0.01-0.06 ; P=0.1480$ and $r^{2}=0.03-0.05$; $P=0.2072$ ), and also remained nonsignificant when all data were combined (respectively: $r^{2}=0.02-0.04 ; P=0.2845$ and $r^{2}=$ $0.02-0.04 ; P=0.2374$ ) (see Table 1 for details).

The decreasing correlation across grades in Fig. 5 reflects a nonlinear trend of considerable interest: an increasing proportion of nonwoody and non-Eurosid I host plants became colonized after the transition to the lower Glossata, and later to the lower Ditrysia and the lower Apoditrysia, but this trend is overshadowed by taxa that return to using woody and Eurosid I host plants after having become $100 \%$ exposed feeders (Fig. 3). When apoditrysian taxa with an exposed feeding score of 1 were omitted from the scatter plots of Fig. 5D, the correlations between the proportion of Eurosid I host plants and the proportion of exposed feeding remained significantly negative also when adding the Apoditrysia $\left(y=-0.42 x+60 ; n=56 ; r^{2}=0.19 ; P=0.001\right)$.

The proportions of woody (Fig. 3B) and Eurosid I host plants (Fig. 3D) are highly correlated throughout the entire dataset (Table 1), as woody lepidopteran host plants tend to belong to the Eurosid I clade, whereas nonwoody lepidopteran host plants tend to belong to other Angiosperm superorders (the correlation between these two traits is less apparent for the Macrolepidoptera in Fig. 3 because of the lower resolution after converting continuous variation to binary states. Woodiness explained $55-60 \%$ of Eurosid I host plant share in the lower Glossata, 63-69\% in the 


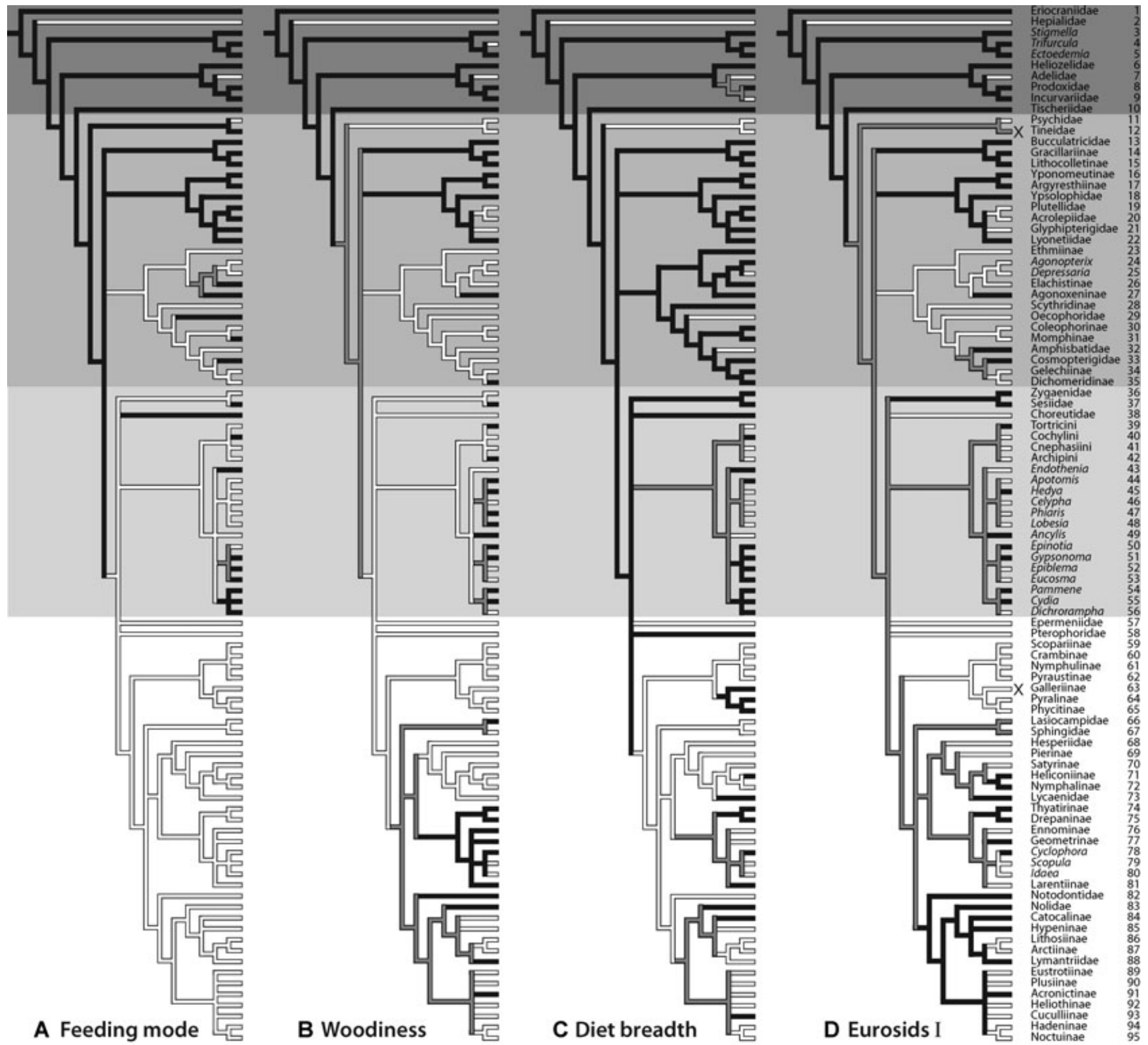

Figure 3. Character state reconstruction of (A) feeding mode, (B) woodiness of host plant, (C) diet breadth, and (D) share of Eurisod I host plants, based on the topology of the tree in Figure 1. The plesiomorphic state is given in black and the derived state in white; gray means equivocal. Background blocks of gray shading indicate the four grades (lower Glossata, lower Ditrysia, lower Apoditrysia, and Macrolepidoptera). An $X$ at an end branch indicates missing data (in figure D: Tineidae and Galleriinae).

lower Ditrysia, 56-75\% in the Apoditrysia, and 62-69\% in the total dataset $(P=0.0140$ in the lower Glossata and $<0.0001$ in the three other cases; Table 1 ). This is essentially why the scatter plot of the percentage woody host plants versus the percentage exposed feeding (not given) is very similar to Figure 4.

A consistent but weaker negative relationship was found between the proportion of generalist feeding (Fig. 3C) and the proportion of woody host plants (Fig. 3B). In the lower Glossata, taxa feeding on woody host plants tend to be (strictly) monophagous, whereas taxa feeding on nonwoody host plants tend to be oligophagous or polyphagous $\left(r^{2}=0.48-0.56 ; P=\right.$ $0.0127)$. The correlation becomes nonsignificant in the lower Ditrysia and the Apoditrysia (Table 1), but when the analyses are done cumulatively the slopes remain consistently and significantly negative in all datasets (Fig. 6).

\section{A PARTIAL ASSESSMENT OF HOW REPRESENTATIVE THE BRITISH DATA ARE}

We tested whether the patterns of host plant use in the British fauna could be considered at least approximately representative 


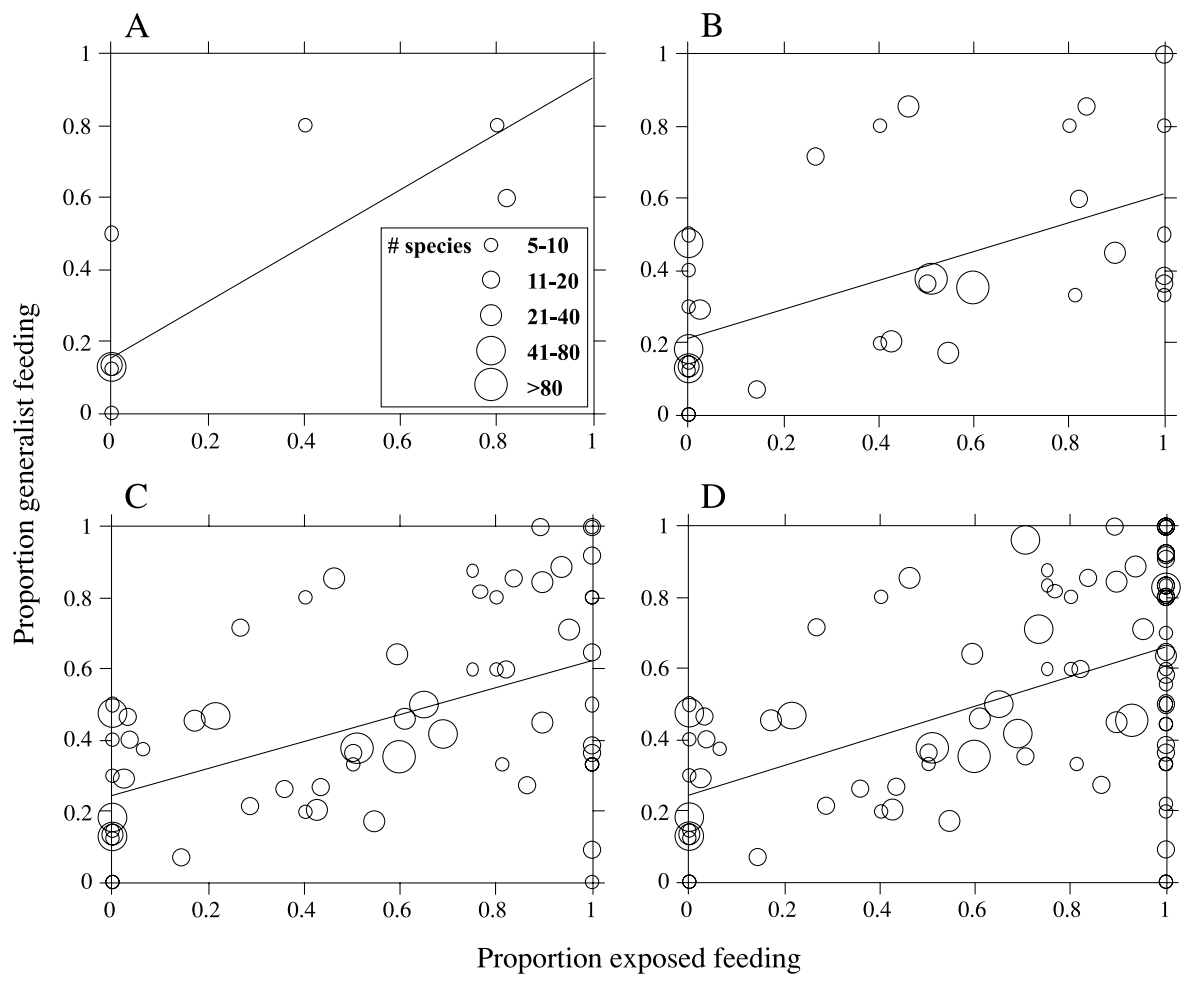

Figure 4. Relationships between the proportion exposed feeding and proportion generalist feeding among the British Lepidoptera plotted in a cumulative manner to illustrate how patterns develop when more derived taxa are included: $(A)$ lower Glossata $(n=10)$, (B) lower Glossata + lower Ditrysia $(n=35)$, (C) lower Glossata + lower Ditrysia + lower Apoditrysia $(n=65)$, and (D) lower Glossata + lower Ditrysia + lower Apoditrysia + Macrolepidoptera $(n=95)$. The size of the circles reflects the sample size category per taxon (see the key in Panel A), but some circles fell exactly on top of each other, so that some panels appear to have a lower sample size than stated in the text and Table 1. Regression lines for panels $A$ and $D$ are given in Table 1. The cumulative regressions were $y=0.40 x+0.21\left(r^{2}=\right.$ $0.34)$ for panel $B$ and $y=0.38 x+0.24\left(r^{2}=0.28\right)$ for panel $C$.

for the world, using data for a single taxon in each of the three basal grades of the lepidopteran phylogeny, that is, the Nepticulidae in the lower Glossata, the Gracillariidae in the lower Ditrysia, and the Pterophoridae in the lower Apoditrysia. The percentages of nepticulid species feeding on monocots, woody dicots, and herbaceous dicots were similar (e.g., $84.2 \%$ and $88.1 \%$ feeding on woody dicots in Britain and the world, respectively; Table 2, left columns) (Fisher's exact test: $P=0.320$ ). The proportional representation of diet breadth categories appeared to be significantly different, with a higher percentage strictly monophagous and a lower percentage monophagous species in the world than in Britain $\left(G_{\mathrm{H}}=29.525\right.$, df $\left.=3, P<0.001\right)$. However, when using only two diet breadth categories (specialist, combining monophagous and strictly monophagous, and generalist, combining oligophagous and polyphagous), the difference was not significant (Fisher's exact test: $P=0.094$ ). Finally, although six of the seven most important host plant families of the Nepticulidae worldwide (together supporting some $65 \%$ of all nepticulid species) belong to the Eurosids I (Fig. 7), the overall worldwide proportion feeding on Eurosids I was significantly smaller than in
Great Britain (61.8\% and 89.5\%, respectively; Fisher's exact test: $P<0.0001)$.

Similar patterns of host plant association were found in the Gracillariidae (Table 2, central columns) when comparing the British data with those of the world. Neither the proportional representation of woodiness categories $\left(G_{\mathrm{H}}=1.403, \mathrm{df}=3, P>0.5\right)$ nor the representation of diet breadth categories $\left(G_{\mathrm{H}}=7.439, \mathrm{df}=\right.$ $3, P>0.05)$ differed significantly between the British data and the worldwide data. Also for the Gracillariidae, the Eurosids I remain the most important host plant clade worldwide, but the share becomes significantly smaller (77.2\% in Britain vs. $55.3 \%$ for the world; Fisher's exact test: $P<0.0001)$ as in the Nepticulidae.

For the Pterophoridae, all four characteristics of host plant association could be compared for the British and worldwide datasets. First, comparable numbers of species are feeding on nonwoody dicots in Britain (97.6\%) and the world $(86.5 \%)$ (Table 2, right columns; Fisher's exact test: $P=0.109$ ). Second, the proportional representation of the diet breadth categories was similar between the two samples $\left(G_{\mathrm{H}}=2.068\right.$, df $=3, P>$ $0.5)$. Third, the distribution of concealed (internal) versus exposed 


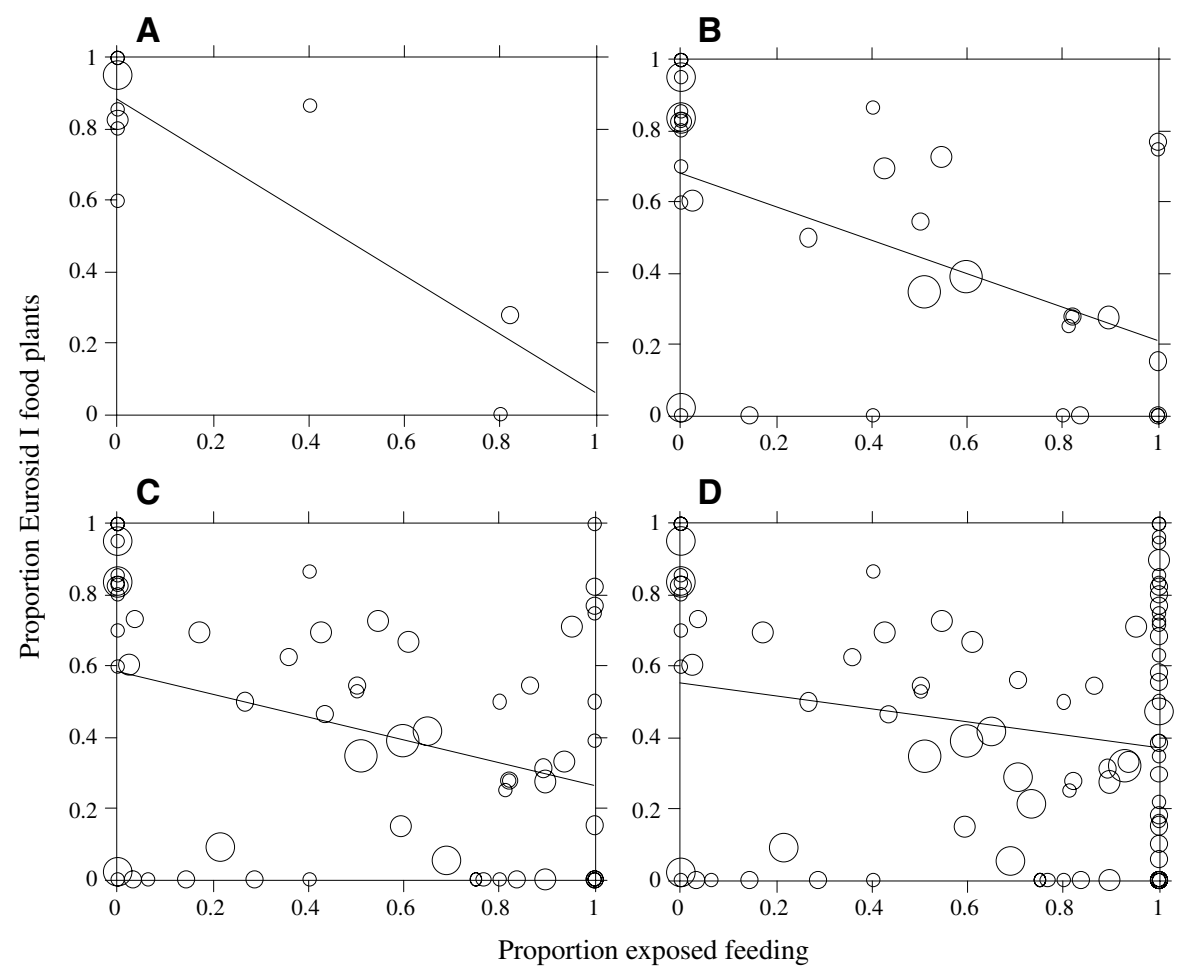

Figure 5. Relationships between the proportion exposed feeding and share of Eurosid I host plants among the British Lepidoptera plotted in a cumulative manner to illustrate how patterns develop when more derived taxa are included (see Fig. 3 for further legend details). Regression lines for panels $A$ and $D$ are given in Table 1. The cumulative regressions were $y=-0.47 x+0.68\left(r^{2}=0.28\right)$ for panel $B$ and $y=-0.32 x+0.58\left(r^{2}=0.13\right)$ for panel C.

(external) feeding did not differ between the two samples $(65.9 \%$ and $53.5 \%$ external feeding, respectively; Fisher's exact test: $P=$ 0.175). Fourth, the fraction of species feeding on Eurosids I worldwide $(11.9 \%)$ was significantly higher than the figure for Britain (7.3\%) (Fisher's exact test: $P=0.002$ ), but remains in the same order of magnitude.

We conclude that, despite the clear differences in the floras and host plant spectra between Britain and the world at lower taxonomic levels, the overall patterns of host plant use of the British Lepidoptera appear to be remarkably representative for those worldwide at higher taxonomic levels.

\section{Discussion}

From the host plant association patterns that we have investigated, it appears that internal feeding, woody Eurosid I host plants, and monophagy have been basal traits in the Lepidoptera (Fig. 3), and that the many cases of monophagy in the lower Apoditrysia and Macrolepidoptera would thus represent independent and convergent reversals. However, any such inference hinges crucially on the assumption that the very detailed data for Britain are at least approximately representative for the worldwide situation, as our quantitative evaluations for three families (Table 2 and Fig. 7) suggest. In the paragraphs below, we further evaluate whether our results for Britain are likely to reflect global patterns of host plant use in the Lepidoptera. Once we have corroborated that this central assumption is indeed reasonable as a working hypothesis, we offer further interpretations of what the results of our study might imply, and what new questions may now be amenable to explicit comparative analysis.

\section{AT WHAT SCALE CAN REGIONAL DATASETS REPRESENT GLOBAL BIODIVERSITY IN COMPARATIVE STUDIES?}

The percentage Eurosid I host plants was significantly lower outside Britain for the Nepticulidae and Gracillariidae, and significantly higher for the Pterophoridae. These differences cannot be explained by a larger taxonomic representation of Eurosids I in the British flora. Of a total of 146 Angiosperm families in Britain, $24(16.4 \%)$ belong to the Eurosids I (Stace 1997), whereas this fraction is 66 out of 405 families (16.3\%) worldwide (Bremer et al. 2003a). We therefore hypothesize that the observed difference in host plant use is due to Eurosid I trees being ecologically more dominant in Britain than in warmer climates, thus providing relatively more niche space to families that specialize on them (e.g., the internally feeding Nepticulidae and Gracillariidae) and less niche space for families that specialize on other food. The only other test in which the British and worldwide data showed 


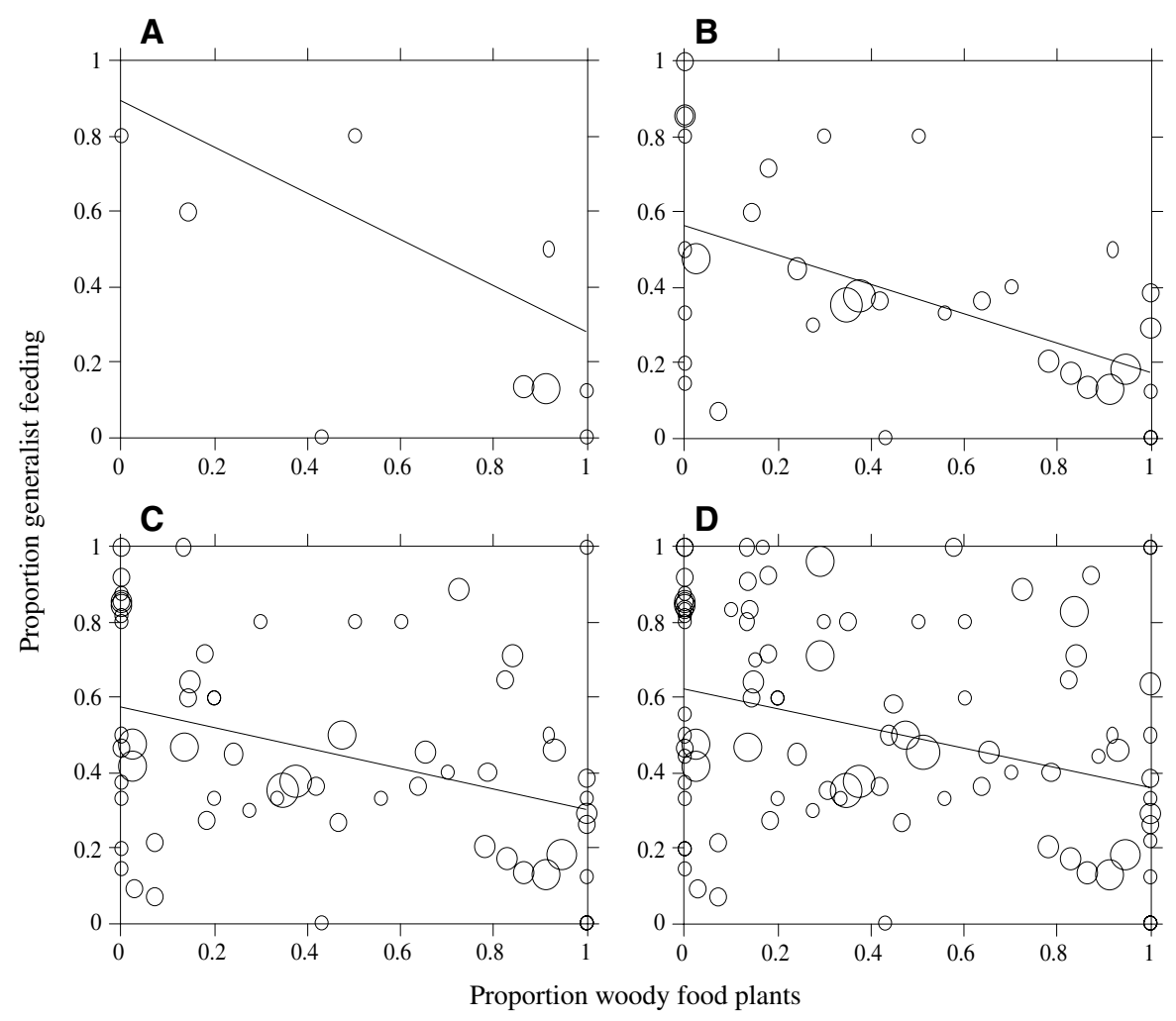

Figure 6. Relationships between the proportion woody host plants and the proportion generalist feeding among the British Lepidoptera plotted in a cumulative manner to illustrate how patterns develop when more derived taxa are included (see Fig. 3 for legend details). Regression lines for panels $A$ and $D$ are given in Table 1. The cumulative regressions were $y=-0.39 x+0.56\left(r^{2}=0.31\right)$ for panel $B$ and $y=-0.27 x+0.57\left(r^{2}=0.13\right)$ for panel $C$.

significant differences of some magnitude concerned the relative proportions of monophagous and strictly monophagous Nepticulidae. However, this mismatch is very likely to be a sampling artifact related to the British nepticulid fauna being much better known than the fauna of the rest of the world. Typically, a new monophagous species of phytophagous insect will first be recorded from a single host plant species. When more data become available this will either lead to an increase in diet breadth (from strictly monophagous by default to monophagous and possibly to oligophagous or even polyphagous) or to strict monophagy being confirmed. Rare species and species in less well-studied regions are thus more likely to be "known" as strictly monophagous.

The hypothesis that sampling effort disproportionally affects the likelihood of species being known as strictly monophagous predicts that such sampling bias should tend to be reduced when more course-grained categories are applied. This was indeed the case, as our analyses that only distinguished between specialist (i.e., monophagous plus strictly monophagous) feeders and generalist (i.e., oligophagous plus polyphagous) feeders gave roughly equal proportions of specialists in the world and Britain for all three families $(0.880$ vs. 0.930 for the Nepticulidae,
0.585 vs. 0.644 for the Pterophoridae, and 0.815 vs. 0.781 for the Gracillariidae).

When the global data for the Nepticulidae are analyzed by major zoogeographical region, diet breadth and proportion of woody dicots differ relatively little among regions (Table 3). This comparison also shows that the significant difference between usage of Eurosid I host plants in Britain and the world is largely caused by the faunas of the southern hemisphere, that is, the Neotropical, Afrotropical, and Australian regions, with the Oriental region being intermediate. As far as the faunas of these southern regions are known, their higher proportions of non-Eurosid I host plants are at least partly due to successful radiations on other angiosperm clades, for example, the genus Pectinivalva on the eucalyptoid Myrtaceae (Rosids) in Australia (Hoare et al. 1997), a group of Stigmella on woody Asteraceae (Euasterid) in New Zealand (Donner and Wilkinson 1989), and a group of Ectoedemia (Fomoria) on Ebenaceae (Asterids) in Africa (Scoble 1983). Still, these same radiations confirm the general pattern of preferential association with dominant woody host plants such as the eucalypts in Australia. A more detailed phylogenetic analysis may well show that the groups that are phylogenetically most related to the fauna of the northern hemisphere (e.g., the 


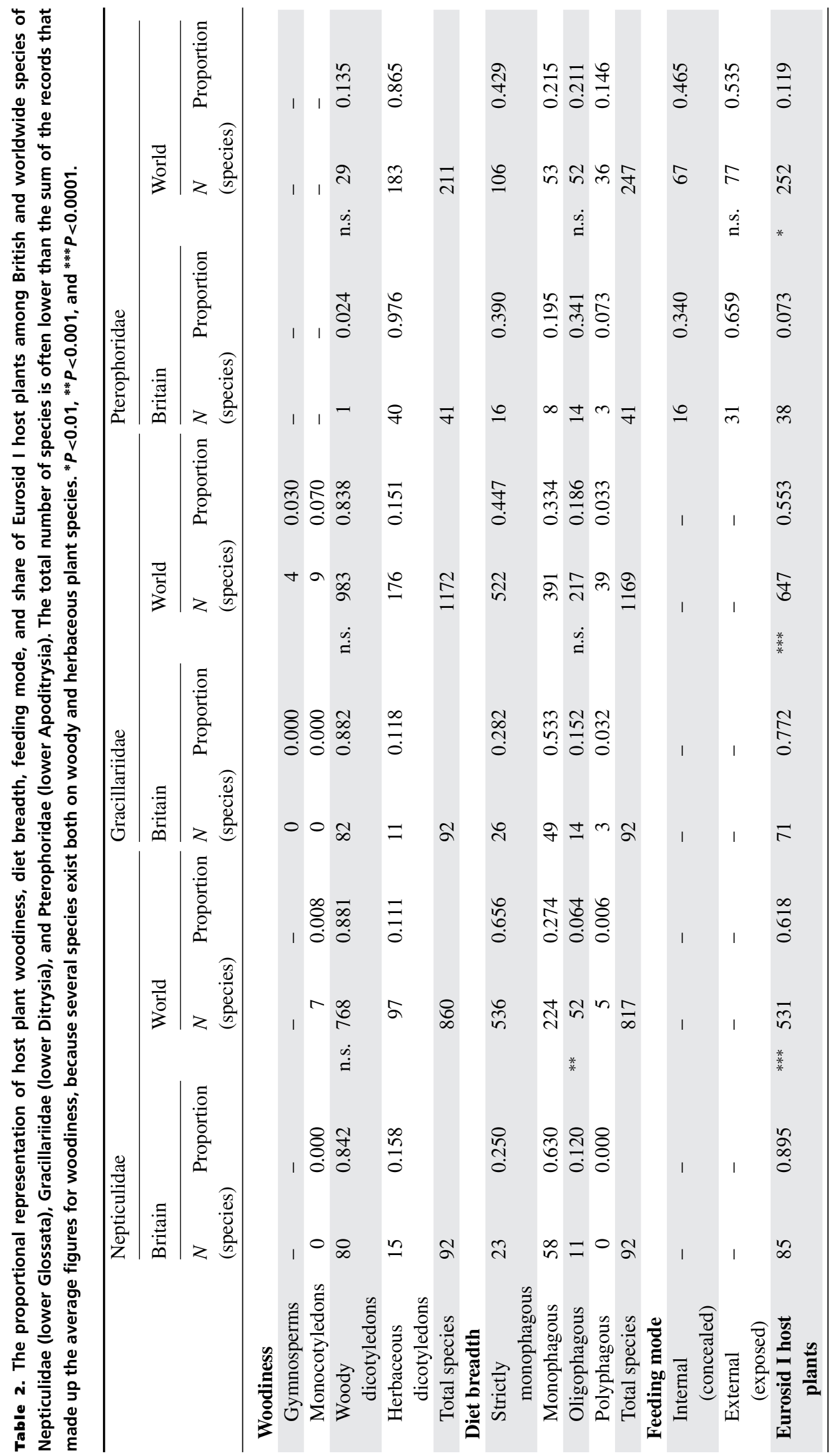




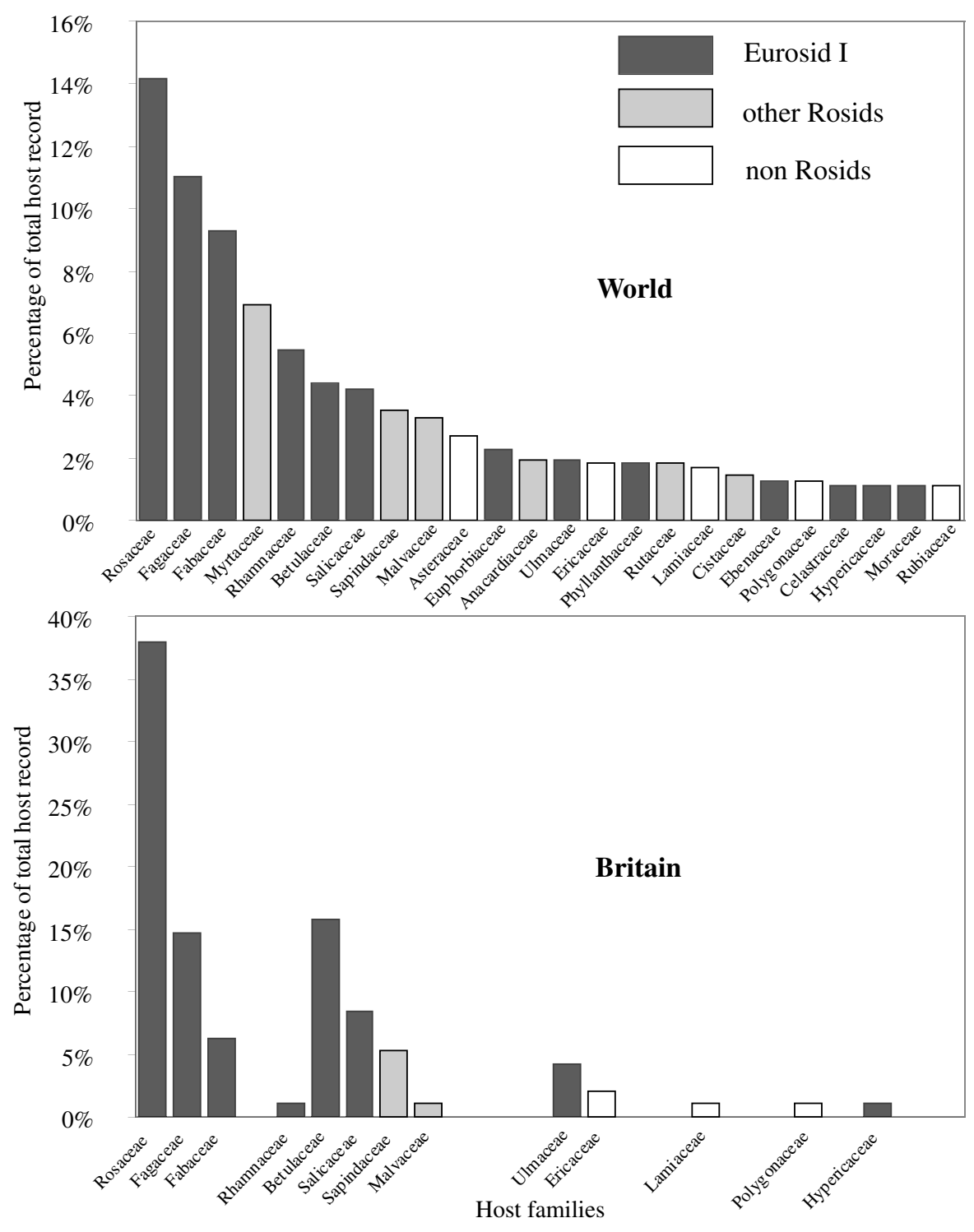

Figure 7. A comparison of the host plant spectra of the Nepticulidae worldwide and in Britain, given as percentage of total host record per family and ranked according to global abundance. Only the $\mathbf{2 4}$ most important host plant families worldwide are given, but for Britain the complete host record is included. Data are partitioned into Eurosids I, other Rosids, and all other categories.

genus Stigmella) have also retained higher proportions of species feeding on Eurosid I hosts in the southern hemisphere.

Monophyletic radiations on non-Eurosid I hosts are also represented in the British fauna. Examples in the lower Ditrysia are: the speciose genus Elachista (Elachistidae: Elachistinae), which always feeds on grasses (Poaceae) and sedges (Cyperaceae; in the tropics also on Commelinaceae), the genus Mompha (Coleophoridae: Momphinae), which almost always feeds on herbaceous Onagraceae, the genus Bryotropha (Gelechiidae: Gelechiinae), which feeds on mosses, and the genus Caryocolum (Gelechiidae: Gelechiinae), which feeds on herbaceous Caryophyllaceae. A similar example from the lower Apoditrysia is the Crambidae (Crambinae), which mostly feed on grasses (Poaceae). Although still fragmentary, the cumulative evidence at our disposal from worldwide data therefore supports our inference that the extensive datasets available for the lepidopteran fauna of the British Isles can be used to analyze evolutionary trends that are likely to be of global significance, provided life-history categories are defined broadly and host plant taxa are specified at a relatively high level.

\section{THE MAJOR EVOLUTIONARY TRANSITION TOWARD LEAF-MINING HERBIVORY IN LEPIDOPTERAN LARVAE}

Our results suggest that there have been two major transitions in the evolution of larval feeding in the Lepidoptera. The first was the switch from litter-feeding to herbivory. The ancestor of the Lepidoptera was probably a very small insect combining traits similar 


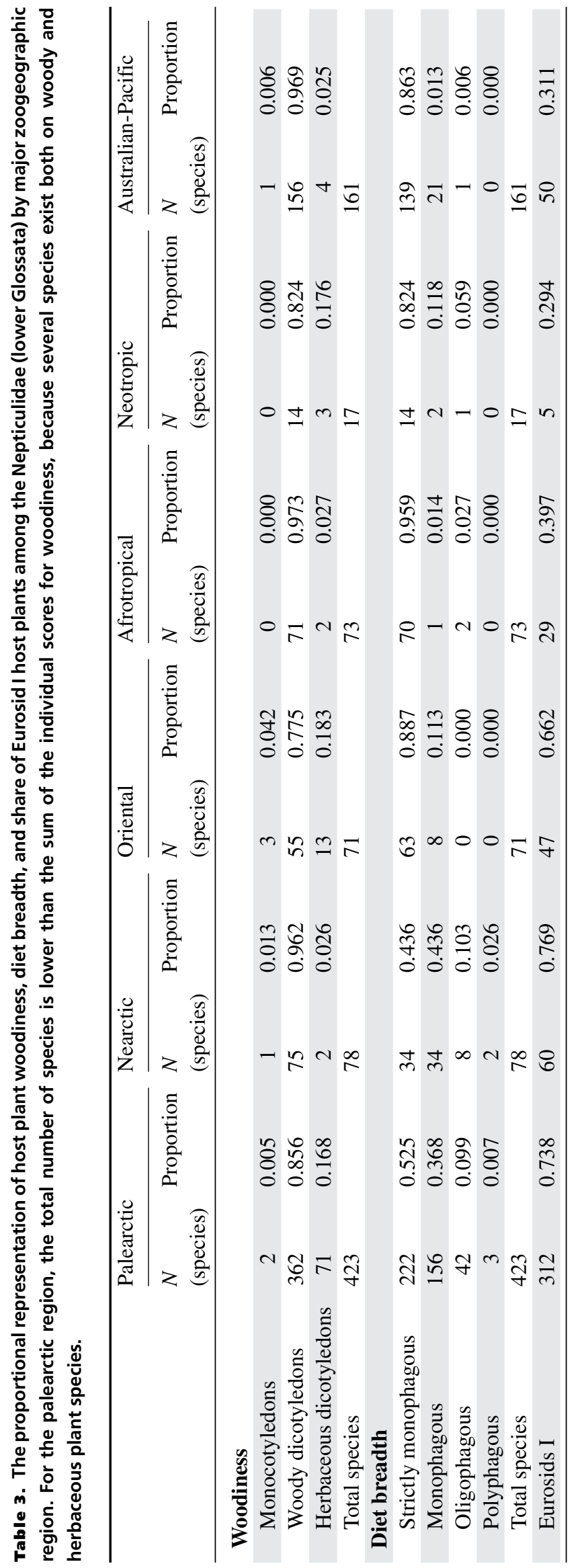

to those of extant Trichoptera and the basal lepidopteran family Micropterigidae (Grimaldi and Engel 2005), including larval feeding on moist leaf-litter potentially supplemented by hyphae of saprophytic fungi (Kristensen 1998b). Specialization on the leaf-litter of single dominant tree species in forests would then have been the precursor for evolving leaf-mining, that is, for obtaining the enzymatic machinery to digest the more nutritious cell contents in freshly fallen leaves before they are degraded by microorganisms. This implies that the evolution of cytokinin-like hormones for creating so called "green islands" in fallen leaves (Engelbrecht et al. 1969; Giron et al. 2007) may have been an early adaptation preceding the evolution of oviposition on still attached leaves and leaf-mining during the growth season of trees.

Present day representatives of the early lepidopteran lineages feeding on angiosperms are leaf-miners of Eurosid I trees, including the Neotropical Heterobathmiidae on Fagales (Nothophagaceae), the Holarctic Eriocraniidae on Fagales and Rosales, and the Holarctic Acanthopteroctetidae on Rosales (Rhamnaceae) (Kristensen 1998a). It is possible that other woody Eurosid I host plants or their ancestors have also been used by early glossatan Lepidoptera that left no extant descendants, but this question remains difficult to address with the sparse fossil record available. The earliest fossil host plant data are for a rich fauna of leaf-miners in the lower Cretaceous (Labandeira et al. 1994), which involved nepticulid leaf-mines on angiosperms belonging to magnoliids (probably Laurales), basal Eudicots (Platanoids), and "rosids." However, it is not clear whether these "rosids" included taxa belonging to the Eurosid I clade. At the time of this fauna, now estimated to be Late Albian (at least 99 million years; LopezVaamonde et al. 2006), a diverse Eudicot Flora was extant, but modern Eurosids I may have been just about to evolve (Magallon and Sanderson 2001; Wikström et al. 2001, 2004). It thus appears that the origin of leaf-mining may have predated the appearance of the extant Eurosids I, and may have taken place on an ancestral clade of Eudicot trees, which was likely characterized by quantitative (tannin-like) defensive compounds rather than by specific toxic secondary compounds (Schoonhoven et al. 2006). Some of these early lineages probably went extinct at the K/T boundary, leaving the lepidopteran lineage associated with Eurosids I as the major clade surviving until the present day. The present data therefore leave open which lineage preceding the Eurosid I clade may have provided the first lepidopteran host plant. However, the well-documented monophyly of the Lepidoptera (Kristensen and Skalski 1998) and the narrow and conserved host plant spectra of the extant lower Glossata (Fig. 3) clearly suggest that the unique transition to larval herbivory required highly specific larval adaptations, so that this innovation most likely arose as a specialized life history on a single species of woody host plant. Once this new herbivorous niche had been acquired, its diversity could apparently only be exploited more broadly after more general larval 
diets and transitions in larval feeding mode had evolved (cf., Janz et al. 2006).

Although the evolution of leaf-mining herbivory was a major innovation, internal feeding also constrained the evolution of larger body sizes, more variable diets, and host shifts (see also Connor and Taverner 1997). The apparent exception that proves the rule are the Hepialidae, whose larvae went underground where thicker plant tissues are softer and where moving from one food source (root) to another did not involve the same risks of desiccation and predation as above ground. Because of these constraints, it is no surprise that the lower Glossata and their ancestors (now represented by extant Eriocranidae and Heterobathmiidae; Fig. 1) show very little adaptive radiation, that is, the extant families appear to be very old and species-poor worldwide. The Nepticuloidea (just over 1000 described species worldwide) are a striking exception. Why this family and partly also the Incurvarioidea became more speciose remains unclear. However, there appears to be a negative correlation between average body size (wing span) and extant species richness across the lower glossatan lineages ( $r=-0.423, P=0.04$; after excluding the Hepialidae whose larvae feed on underground roots, so that predation pressure and desiccation constraints for external feeding are much less severe). It is therefore tempting to speculate that the small bodied lineages were less prone to extinction because they maintained larger effective population sizes and higher passive dispersal rates. This hypothesis would be consistent with the observation that it was not resource diversity itself that drove speciation rates in these early lineages (Janz et al. 2006) as most of the successful radiations within the Nepticuloidea remained also restricted to core Eurosid I orders such as Rosales, Fagales and Fabales (Fig. 7). In fact, the genera that made shifts to other angiosperm orders invariably remained species-poor, both within the Nepticuloidea and within the Hepialidae and Incurvarioidea. The convergent successful Australian radiations on Myrtales in several families (Nepticulidae, Heliozelidae, and Incurvariidae; Common 1990) appear to be exceptions. However, this is possibly not really the case as the Myrtales belong to the Rosids, and may in fact be more closely related to the Eurosids I (Soltis et al. 2000, 2005), although the exact relationships in this group are not yet convincingly clarified. These patterns suggest that early colonizations of alternative host plant taxa have been attempted, but had a high probability of going extinct, consistent with the fossil record of nepticulid leaf mines on magnoliids, a host plant taxon that is unknown to harbor extant nepticuloid larvae (Labandeira et al. 1994).

\section{THE MULTIPLE LATER TRANSITIONS TO EXPOSED LARVAL FEEDING}

The second major transition in the evolution of lepidopteran larval feeding occurred multiple times but always involved shifts from concealed (internal) to exposed (external) phytophagous feeding. Where the previous transition toward herbivory had probably mostly required internal adaptations in digestive enzymes, the second transition required major external adaptations for larval attachment to and locomotion on leaves and for desiccation tolerance, together with additional digestive adaptations to cope with increased fiber and reduced nitrogen content of the diet (Southwood 1973). It appears that several independent steps toward these decisive innovations have been attempted in the lower Glossata, but that they were not very successful. For example, the larvae of many species of the Incurvarioidea (particularly in Adelidae and Incurvariidae) likely evolved some desiccation resistance and some enhanced mobility (as case and shield bearers, which feed externally for at least part of their larval life (Davis 1998). However, their evolutionary success remained limited, possibly because the case bearers stop feeding on live plant material and resume to feed on litter in later larval stages, so that selection for higher desiccation resistance remained limited. Also the obligate leaf-mining Tischerioidea with their unique open leaf-mines may represent a stalled development toward more desiccation-resistant larval cuticles.

Representatives of the lower Ditrysian superfamilies have well-developed legs and are likely to have more desiccationtolerant larvae than the lower Glossata, but their actual mobility remains limited and they still use a variety of devices such as silk threads, leaf folds, and cases to secure their attachment to the plant surface. Some of the most successful clades have retained leaf-mining (e.g., the Gracillarioidea, including the Gracillariidae being the principal family of plant leaf-mining Lepidoptera with some 2000 described species worldwide), suggesting that the alternative larval life styles of related groups were partial improvements at best. The lower Ditrysia are further characterized by a broadening of the host plant spectrum (more Angiosperm superorders and more nonwoody and nonapparent [Feeney 1976] hosts) and an increasing percentage of polyphagous species. Using nonEurosid I host plants also increased in frequency and intensity, particularly in the Plutellidae and Acrolepiidae, and in the genus Depressaria). The Tineoidea were apparently the first Ditrysian clade to evolve (Davis and Robinson 1998) and they became quite speciose. They have highly derived nonherbivorous larval feeding habits (many detritophagous, fungivorous, and lichenovorous species; some species feeding on keratin and chitin), and produce a variety of "cases" from which they feed. Interestingly, however, some clades have externally feeding larvae, such as the relatively large Myrmecozelinae, indicating that a direct link between body size and external feeding may already have become established here.

When we move further toward the more derived lower Apoditrysia, external feeding further increases in frequency in the Tortricoidea, the Pterophoroidea, and the Pyraloidea, although 
caterpillars of many species retain concealed habits such as leaf rolling and stem boring. Some tortricids even have completely concealed internal feeding. This has previously been considered to represent a plesiomorphic trait carried over from lower ditrysian heritage (Powell 1964), but now seems more likely to be a secondary reversal, as this feeding habit is particularly common in some of the derived tortricid tribes (Horak 1998). Throughout the lower Apoditrysia larval mobility remains very restricted. This implies that female oviposition-site selection still largely determines where a caterpillar will develop, as larvae hardly have the means to actively change their likelihood of survival by migration when an ovipositing female has chosen an unsuitable host plant or when conditions become adverse. However, the proportion of generalist feeders continued to increase (Fig. 2) and the monophagous species tended to become specialized on host plants other than the ones used by the lower Glossata. All this is consistent with the Janz et al. (2006) scenario of diversification along multiple niche axes followed by various forms of secondary specialization as monophagous feeders, recolonizers of specific woody or herbal host plants, and occasional reversals to internal feeding habits. However, most of these later specializations have not produced independent radiations, as sister taxa have often retained more general life histories, at least until the emergence of the Macrolepidoptera (Fig. 3).

Finally, the Macrolepidoptera are, with very few exceptions (none of them common enough to appear as darker colored branches in Fig. 3), exposed feeders during their entire larval life. They are generally large-sized butterflies and moths, with highly mobile larvae that can move from plant to plant, even directly after hatching. If we were to identify a third major transition in lepidopteran life histories, it would be this shift toward larval body sizes that effectively precluded any form of successful reversal to feeding within the host plant. Although the earlier transition away from obligate internal feeding appears to have opened multiple opportunities for adopting more generalist feeding habits, the permanent abandonment of internal feeding because of increased body size and mobility opened up completely novel ways of exploiting the same wide range of host plants that earlier lepidopteran lineages had already colonized. It is therefore no surprise that we find the most substantial radiations in the Macrolepidoptera, particularly in the Hesperioidea/Papilionoidea, Geometroidea, and Noctuoidea, which together comprise about half of all described lepidopteran species. Across the 30 taxa of Macrolepidoptera that we distinguished, there were essentially no correlations between variables of host plant woodiness, larval feeding mode and diet breadth, and the (non) use of Eurosid I host plant taxa, so that we did not present any of these results in figures or tables. This is not because trends are necessarily always absent, but because they are unlikely to be shared between lineages. For example, Janz and Nylin (1998) identified a positive correlation between generalist feeding and the use of woody host plants in butterflies, which is opposite to trends that we observed in the more basal lepidopteran clades. However, their analysis concerns only six of our 30 macrolepidopteran taxa, indicating that unconstrained larval mobility makes it much more difficult to predict larval feeding syndromes and host plant associations. In spite of this, we did include the Macrolepidoptera in our cumulative analyses, because (1) they continue many of the trends that were already apparent in the lower Apoditrysia, but in a less predictable way and (2) they show many convergent tendencies to becoming secondarily monophagous on woody Eurosid I host plants and thus represent secondary specializations derived from generalists as envisaged by Janz et al. (2006).

\section{COMPARING LIFE-HISTORY SYNDROMES ACROSS THE MAJOR CLADES OF INSECTS WITH PHYTOPHAGOUS LARVAE}

A striking consequence of our analyses is that it was apparently not primarily herbivory that enabled the Lepidoptera to become the largest radiation of phytophagous insects (Scoble 1992), but the additional key innovations of external feeding. Our results therefore corroborate the conclusion by Connor and Taverner (1997) that leaf-mining life histories did not result in many adaptive radiations, but our study emphasizes more directly that external feeding was a key prerequisite for being able to exploit the available variation in resource opportunities and thus for the potential to realize adaptive radiation. Further comparative evidence for this contention comes from the agromyzid flies where leaf-mining is also the ancestral state (Dempewolf 2005), but where morphological constraints (fly larvae lost rather than elaborated leg-like structures during dipteran radiation) prevented them from leaving the endophytic life style behind in derived lineages (Dempewolf 2005). In contrast, the Tenthredinoidea, particularly in the nematine sawflies, repeatedly evolved endophagy (mining, galling, and boring) from ancestral external feeding, which mostly produced a significantly higher degree of monophagy and lower species richness compared to externally feeding sister groups (Nyman et al. 2006). The single major exceptions are the euurine gallinducers on Salicaceae (Nyman et al. 2006). The sawfly wasps are an evolutionary old group, similar to the Lepidoptera, and have many monophagous clades that are associated with among others woody Eurosids I (Ward et al. 2003), in contrast to the agromyzid flies, which are a much more recent clade and are almost invariably associated with nonwoody host plants from a large array of angiosperm orders (Spencer 1990; Ward et al. 2003). Other important large radiations of holometabolous insects with phytophagous larvae are the chrysomelid and curculionid beetles, whose evolutionary developments are relatively well understood (Marvaldi et al. 2002; Farrell and Sequeira 2004). Also these taxa were initially exclusively concealed feeders, often on 
Gymnosperms and woody Angiosperms (Ward et al. 2003), and have evolved external feeding in some lineages (Farrell and Sequeira 2004) but not or rarely in others (Marvaldi et al. 2002; Farrell and Sequeira 2004). In contrast to the large number of holometabolous insects with endophagous larvae, including the basal taxa in most of the major lineages, the hemimetabolous insects are feeding externally, with the exception of the gall formers that are often found in clades with piercing/sucking mouthparts (Winkler and Mitter 2008).

\section{NEW QUESTIONS ON PHYTOPHAGOUS LARVAL ADAPTATIONS THAT FACILITATE OR CONSTRAIN MAJOR TRANSITIONS IN FEEDING MODE}

Our comparative understanding of the selective forces that shaped and diversified phytophagous insect clades would benefit greatly from better phylogenies and more complete life-history inventories, particularly of the little studied tropical faunas. However, similar to the present study, such databases would add indirect comparative evidence, but no deeper insight in the key adaptations that initiated and elaborated radiations. An additional research program that deserves to be developed should therefore focus on comparing adaptations in digestive traits across major transitions in larval feeding mode. The first lepidopteran transition of interest would be comparing the detrivorous micropterigoid sister group of all other Lepidoptera (Fig. 1) and the basal lower Glossatan clades (Heterobathmiidae and Eriocraniidae), which have exclusive leaf-mining habits. Other such comparisons could be made among sister groups in more derived clades that have, respectively, exclusively concealed feeding on high quality internal plant tissue and external feeding on larger quantities of less digestible plant material. The coming years will see genomic databases accumulating also for these non model taxa, so that the genetic basis of digestive adaptations can likely be elucidated.

Studies of this kind should be complemented with comparative investigations into larval desiccation tolerance and the ways in which cuticular wax layers and their cuticular hydrocarbons regulate evaporation. Such studies could reveal which traits have constrained evolutionary developments toward the typical derived characteristics associated with external herbivory, in particular when they would be combined with studies of the genes coding for these traits. These approaches would complement and invigorate ongoing work on metabolic and behavioral defenses against secondary plant compounds, which has up till now been the major research angle to explain differences between monophagous and polyphagous feeding habits (Schoonhoven et al. 2006; Mao et al. 2006; Wheat et al. 2007). Ultimately, these studies should shed light on when larval specialization is likely to be an evolutionary dead end, as in the agromyzid flies after they became obligate leaf-miners, and when it is not, as in the basal Lepidoptera that became specialized leaf-miners first and later evolved multiple ways to exploit host plants in a more flexible manner.

\section{ACKNOWLEDGMENTS}

The compilation of data for this project started in the mid-1980s when the authors were associated with the Department of Biosystematics at the Free University of Amsterdam. We thank J. Vink for assistance in the early phases of database design and W. van Ginkel for invaluable help in making the final database. D. Nash provided logistic help and assistance with the statistical analyses, N. Isaac answered queries about CAIC, N. P. Kristensen advised on various more general issues, and J. van Arkel designed Figures 1 and 3. C. Lopez-Vaamonde and Willy and J. de Prins made their host data for the host plants of the Gracillariidae available before publication and $\mathrm{C}$. Gielis provided similar information on the worldwide host plant associations in the Pterophoridae. The manuscript benefited from insightful comments by R. de Jong.

\section{LITERATURE CITED}

Ackermann, M., and M. Doebeli. 2004. Evolution of niche width and adaptive diversification. Evolution 58:2599-2612.

Ackery, P. R., R. de Jong, and R. I. Vane-Wright. 1998. The butterflies: Hedyloidea, Hesperioidea and Papilionoidea. Pp. 262-300 in N. P. Kristensen, ed. Lepidoptera, moths and butterflies, 1. Evolution, systematics and biogeography. Handbook of zoology 4 (35). De Gruyter, Berlin, New York.

Braby, M. F., and J. W. H. Trueman. 2006. Evolution of larval host plant associations and adaptive radiation in pierid butterflies. J. Evol. Biol. 19:1677-1690.

Bremer, B., K. Bremer, M. W. Chase, J. L. Reveal, D. E. Soltis, P. S. Soltis, P. F. Stevens, A. A. Anderberg, M. F. Fay, P. Goldblatt, et al. 2003a. An update of the Angiosperm Phylogeny Group classification for the orders and families of flowering plants: APG II. Bot. J. Linn. Soc. 141: 399-436.

Bremer, K., B. Bremer, and M. Thulin. 2003b. Introduction to phylogeny and systematics of flowering plants. Acta Universitatis Upsaliensis, Upsala, Sweden.

Brower, L. P., and J. V. Z. Brower. 1964. Birds, butterflies, and plant poisons: a case study in ecological chemistry. Zoologica (N. Y.) 49:137159.

Common, I. F. B. 1990. Moths of Australia. E. J. Brill, Leiden, New York.

Connor, E. F., and M. P. Taverner. 1997. The evolution and adaptive significance of the leaf-mining habit. Oikos 79:6-25.

Davis, D. R. 1998. The monotrysian Heteroneura. Pp. 65-90 in N. P. Kristensen, ed. Lepidoptera, moths and butterflies, 1. Evolution, systematics and biogeography. Handbook of zoology 4 (35). De Gruyter, Berlin, New York.

Davis, D. R., and G. S. Robinson. 1998. The Tineoidea and Gracillarioidea. Pp. 91-117 in N. P. Kristensen, ed. Lepidoptera, moths and butterflies, 1. Evolution, systematics and biogeography. Handbook of zoology 4 (35). De Gruyter, Berlin, New York.

de Jong, R., R. I. Vane Wright, and P. R. Ackery. 1996. The higher classification of butterflies (Lepidoptera): problems and prospects. Entomol. Scand. 27:65-101.

De Prins, W., and J. De Prins. 2005. Gracillariidae (Lepidoptera). World Cat. Ins. 6:1-495.

Dempewolf, M. 2005. Dipteran leaf miners. Pp. 407-429 in A. Raman, C. W. Schaefer, and T. M. Withers, eds. Biology, ecology and evolution of gall-inducing arthropods: volume 1. Science Publishers, Inc., Enfield, Middlesex, U.K. 
Donner, H., and C. Wilkinson. 1989. Nepticulidae (Insecta: Lepidoptera). Fauna Nw Zealand 16:1-88.

Ehrlich, P. R., and P. H. Raven. 1964. Butterflies and plants: a study in coevolution. Evolution 18:586-608.

Emmet, A. M. 1991. Chart showing the life history and habits of the British Lepidoptera. Pp. 61-303 in A. M. Emmet and J. Heath, eds. The moths and butterflies of Great Britain and Ireland. 7 (2): Lasiocampidae Thyratiridae with life history chart of the British Lepidoptera. Harley Books, Colchester, Essex, U.K.

Engelbrecht, L., U. Orban, and W. Heese. 1969. Leaf-miner caterpillars and cytokinins in the "green islands" of autumn leaves. Nature (Lond.) 223:319-321.

Farrell, B. D., and C. Mitter. 1998. The timing of insect/plant diversification: might Tetraopes (Coleoptera: Cerambycidae) and Asclepias (Asclepiadaceae) have co-evolved? Biol. J. Linn. Soc. 63:553-577.

Farrell, B. D., and A. S. Sequeira. 2004. Evolutionary rates in the adaptive radiation of beetles on plants. Evolution 58:1984-2001.

Feeney, P. 1976. Plant apparency and chemical defense. Recent Adv. Phytochem. 10:1-40.

Friedlander, T. P., J. C. Regier, C. Mitter, D. L. Wagner, and Q. Q. Fang. 2000. Evolution of heteroneuran Lepidoptera (Insecta) and the utility of dopa decarboxylase for Cretaceous-age phylogenetics. Zool. J. Linn. Soc. 130:213-234.

Gaston, K. J., and D. Reavey. 1989. Patterns in the life histories and feeding strategies of British Macrolepidoptera. Biol. J. Linn. Soc. 37:367-381.

Gaston, K. J., D. Reavey, and G. R. Valladares. 1992. Intimacy and fidelity - internal and external feeding by the British Microlepidoptera. Ecol. Entomol. 17:86-88.

Gielis, C. 2003. Pterophoroidea and Alucitoidea (Lepidoptera). Apollo Books, Stenstrup, Denmark.

Giron, D., W. Kaiser, N. Imbault, and J. Casas. 2007. Cytokinin-mediated leaf manipulation by a leafminer caterpillar. Biol. Lett. 3:340-343.

Grimaldi, D. A., and M. S. Engel. 2005. Evolution of the insects. Cambridge Univ. Press, New York.

Heraty, J. 2009. Parasitoid diversity and insect pest management. Pp. 445462 in F. R. Foottit and P. H. Adler, eds. Insect biodiversity: science and society. Blackwell, Chichester, UK.

Hoare, R. J. B., R. Johansson, E. J. van Nieukerken, and E. S. Nielsen. 1997. Australian Nepticulidae (Lepidoptera): redescription of the named species. Entomol. Scand. 28: 1-28.

Hodges, R. W. 1998. The Gelechioidea. Pp. 130-158 in N. P. Kristensen, ed. Lepidoptera, moths and butterflies, 1. Evolution, systematics and biogeography. Handbook of zoology 4 (35). De Gruyter, Berlin, New York.

Holloway, J. D., and P. D. N. Hebert. 1979. Ecological and taxonomic trends in macrolepidopteran host plant selection. Biol. J. Linn. Soc. 11: 229-251.

Horak, M. 1998. The Tortricoidea. Pp. 199-215 in N. P. Kristensen, ed. Lepidoptera, moths and butterflies, 1. Evolution, systematics and biogeography. Handbook of zoology 4 (35). De Gruyter, Berlin, New York.

Janz, N., and S. Nylin. 1998. Butterflies and plants: a phylogenetic study. Evolution 52:486-502.

Janz, N., S. Nylin, and N. Wahlberg. 2006. Diversity begets diversity: host expansions and the diversification of plant-feeding insects. BMC Evol. Biol. 6:4

Janzen, D. H. 1988. Ecological characterization of a Costa Rican dry forest caterpillar fauna. Biotropica 20:120-135.

Jermy, T. 1984. Evolution of insect - host plant relationships. Am. Nat. 124:609-630

. 1993. Evolution of insect-plant relationships - a devils advocate approach. Entomologia Exp. Appl. 66:3-12.
Karsholt, O., and J. Razowski, eds. 1996. The Lepidoptera of Europe. A distributional checklist. Apollo Books, Stenstrup, Denmark.

Kitching, I. J., and J. E. Rawlins. 1998. The Noctuoidea. Pp. 355-401 in N. P. Kristensen, ed. Lepidoptera, moths and butterflies, 1. Evolution, systematics and biogeography. Handbook of zoology 4 (35). De Gruyter, Berlin, New York.

Kristensen, N. P., ed. 1998a. Lepidoptera, moths and butterflies,1. Evolution, systematics and biogeography. Handbook of zoology 4 (35). De Gruyter, Berlin, New York.

. 1998b. The non-Glossatan moths. Pp. 41-49 in N. P. Kristensen, ed. Lepidoptera, moths and butterflies, 1. Evolution, systematics and biogeography. Handbook of zoology 4 (35). De Gruyter, Berlin, New York.

Kristensen, N. P., and A. W. Skalski. 1998. Phylogeny and palaeontology. Pp. 7-25 in N. P. Kristensen, ed. Lepidoptera, moths and butterflies, 1. Evolution, systematics and biogeography. Handbook of zoology 4 (35). De Gruyter, Berlin, New York.

Kristensen, N. P., M. Scoble, and O. Karsholt. 2007. Lepidoptera phylogeny and systematics: the state of inventorying moth and butterfly diversity. Pp. 699-747 in Z.-Q. Zhang, and W. A. Shear, eds. Linnaeus tercentenary: progress in invertebrate taxonomy. Zootaxa 1668: $1-766$.

Kyrki, J. 1990. Tentative reclassification of Holarctic Yponomeutoidea (Lepidoptera). Nota Lepid. 13:28-42.

Labandeira, C. C., D. L. Dilcher, D. R. Davis, and D. L. Wagner. 1994. Ninetyseven million years of angiosperm-insect association: paleobiological insights into the meaning of coevolution. Proc. Natl. Acad. Sci. USA 91:12278-12282.

Lafontaine, J. D., and M. Fibiger. 2006. Revised higher classification of the Noctuoidea (Lepidoptera). Can. Entomol. 138:610-635.

Lopez-Vaamonde, C., H. C. J. Godfray, and J. M. Cook. 2003. Evolutionary dynamics of host-plant use in a genus of leaf-mining moths. Evolution 57:1804-1821.

Lopez-Vaamonde, C., N. Wikstrom, C. Labandeira, H. C. J. Godfray, S. J. Goodman, and J. M. Cook. 2006. Fossil-calibrated molecular phylogenies reveal that leaf-mining moths radiated millions of years after their host plants. J. Evol. Biol. 19:1314-1326.

Maddison, W. P., and D. R. Maddison. 2003. MacClade: analysis of phylogeny and character evolution, v. 4.6, Sinauer. Sunderland, MA.

Magallon, S., and M. J. Sanderson. 2001. Absolute diversification rates in Angiosperm clades. Evolution 55:1762-1780.

Mao, W., S. Rupasinghe, A. R. Zangerl, M. A. Schuler, and M. R. Berenbaum. 2006. Remarkable substrate-specificity of CYP6AB3 in Depressaria pastinacella, a highly specialized caterpillar. Insect Mol. Biol. 15:169179.

Marvaldi, A.-E., A.-S. Sequeira, C.-W. O'Brien, and B.-D. Farrell. 2002. Molecular and morphological phylogenetics of weevils (Coleoptera, Curculionoidea): do niche shifts accompany diversification? Syst. Biol. 51:761-785.

Mattson, W. J., R. K. Lawrence, R. A. Haack, D. A. Herms, and P. J. Charles. 1988. Defensive strategies of woody plants against different insect-feeding guilds to plant ecological strategies and intimacy of association with insects. Pp. 3-38 in W. J. Mattson, J. Levieux, and C. Bernard-Dagan, eds. Mechanisms of woody plant defenses against insects: Search for pattern. Springer Verlag, New York.

Menken, S. B. J. 1996. Pattern and process in the evolution of insect-plant associations: Yponomeuta as an example. Entomologia Exp. Appl. 80:297305.

Menken, S. B. J., and P. Roessingh. 1998. Evolution of insect - plant associations: sensory perception and receptor modifications direct food specialization and host shifts in phytophagous insects. Pp. 145-156. in 
D. J. Howard, and S. H. Berlocher, eds. Endless forms: species and speciation. Oxford Univ. Press, New York, Oxford.

Mitchell, A., C. Mitter, and J. C. Regier. 2000. More taxa or more characters revisited: combining data from nuclear proteinencoding genes for phylogenetic analyses of Noctuoidea (Insecta: Lepidoptera). Syst. Biol. 49:202-224.

. 2006. Systematics and evolution of the cutworm moths (Lepidoptera: Noctuidae): evidence from two protein-coding nuclear genes. Syst. Entomol. 31:21-46.

Nielsen, E. S., and D. R. Davis. 1985. The first Southern Hemisphere prodoxid and the phylogeny of the Incurvarioidea (Lepidoptera). Syst. Entomol. 10:307-322.

Nieukerken, E. J. van 1986. Systematics and phylogeny of Holarctic genera of Nepticulidae (Lepidoptera, Heteroneura: Monotrysia). Zool. Verh. 236:1-93.

Nosil, P. 2002. Transition rates between specialization and generalization in phytophagous insects. Evolution 56:1701-1706.

Nosil, P., and A. O. Mooers. 2005. Testing hypotheses about ecological specialization using phylogenetic trees. Evolution 59:22562263.

Nyman, T., B. D. Farrell, A. G. Zinovjev, and V. Vikberg. 2006. Larval habits, host-plant associations, and speciation in nematine sawflies (Hymenoptera: Tenthredinidae). Evolution 60:1622-1637.

Pellmyr, O. 2003. Yuccas, yuccca moths, and coevolution: a review. Ann. Mo. Bot. Gdn. 90:35-55.

Pierce, N. E. 1995. Predatory and parasitic Lepidoptera: carnivores living on plants. J. Lep. Soc. 49:412-453.

Powell, J. A. 1964. Biological and taxonomic studies on tortricine moths, with reference to the species in California (Lepidoptera: Tortricidae). Univ. Calif. Publ. Entomol. 32:1-317.

1980. Evolution of larval food preferences in Microlepidoptera. Ann. Rev. Entomol. 25:133-159.

Price, P. W. 2002. Species interactions and the evolution of biodiversity. Pp. 125 in C. M. Herrera and O. Pellmyr, eds. Plant-animal interactions: an evolutionary approach. Blackwell Science, Oxford, UK.

. 1995. Comparative analysis by independent contrasts (CAIC): an apple Macintosh application for analysing comparative data. Cabios 11:247-251.

Schoonhoven, L. M., J. J. A. van Loon, and M. Dicke. 2006. Insect-plant biology. Oxford Univ. Press, Oxford, UK.

Scoble, M. J. 1983. A revised cladistic classification of the Nepticulidae (Lepidoptera) with descriptions of new taxa mainly from South Africa. Transv. Mus. Monogr. 2:1-105.

.1992. The Lepidoptera: form, function and diversity. Oxford Univ. Press, New York.
Scott, J. A. 1986. The butterflies of North America. Stanford Univ. Press, Stanford, CA.

Sokal, R. R., and F. J. Rohlf. 1995. Biometry. 3rd ed. Freeman, San Francisco, CA.

Solis, M. A., and C. Mitter. 1992. Review and preliminary phylogenetic analysis of the subfamilies of the Pyralidae (sensu stricto) (Lepidoptera: Pyraloidea). Syst. Entomol. 17:79-90.

Soltis, D. E., P. S. Soltis, M. W. Chase, M. E. Mort, D. C. Albach, M. Zanis, V. Savolainen, W. H. Hahn, S. B. Hoot, M. F. Fay, et al. 2000. Angiosperm phylogeny inferred from $18 \mathrm{~S}$ rDNA, $r b c L$, and $a t p B$ sequences. Bot. J. Linn. Soc. 133:381-461.

Soltis, D. E., P. S. Soltis, P.K. Endress, and M. W. Chase. 2005. Phylogeny and evolution of angiosperms. Sinauer, Sunderland, U.K.

Southwood, T. R. E. 1973. The insect/plant relationship - an evolutionary perspective. Pp. 3-30 in H. F. v. Emden, ed. Insect plant relationships. Blackwell Scientific Publications Ltd., Lond.

Spencer, K. A. 1990. Host specialization in the world Agromyzidae (Diptera). Kluwer Academic Publishers, Dordrecht, The Netherlands, Boston, MA, Lond.

Stace, C. A. 1997. New flora of the British Isles. 2nd ed. [data from ed. 1, 1991]. Cambridge Univ. Press, Cambridge, UK.

Thompson, J. N. 1994. The coevolutionary process. Univ. of Chicago Press, Chicago, IL.

Tilmon, K. J. (Ed.) 2008. Specialization, speciation, and radiation: the evolutionary biology of herbivorous insects. Univ. of California Press, Berkeley, CA, 789 pp.

Ward, L. K., A. Hackshaw, and R. T. Clarke. 2003. Do food-plant preferences of modern families of phytophagous insects and mites reflect past evolution with plants? Biol. J. Linn. Soc. 78:51-83.

Wheat, C. W., H. Vogel, U. Wittstock, M. F. Braby, D. Underwood, and T. Mitchell-Olds. 2007. The genetic basis of a plant-insect coevolutionary key innovation. Proc. Natl. Acad. Sci. USA 104:20427-20431.

Wikström, N., V. Savolainen, and M. W. Chase. 2001. Evolution of the angiosperms: calibrating the family tree. Proc. R. Soc. Lond. B 268:22112220.

2004. Angiosperm divergence times: congruence and incongruence between fossils and sequence divergence estimates. Pp. 142-165 in P. C. Donoghue, and M. P. Smith, eds. Telling the evolutionary time. Molecular clocks and the fossil record. CRC Press, Boca Raton, FL.

Winkler, I. S., and C. Mitter. 2008. The phylogenetic dimension of insect/plant interactions: a summary of recent evidence. Pp. 240-263 in K. Tilmon, ed. Specialization, speciation, and radiation: the evolutionary biology of herbivorous insects. Univ. of California Press, Berkeley, CA.

Associate Editor: J. Feder 
Appendix. (A) The dataset used in this study. Means of four host plant-associated traits for each of the 95 taxa (rank numbers correspond with those in Fig. 1) with the sample size category of species number (1: 5-10, 2: 11-20, 3: 21-40, 4: 41-80, and 5: more than 80 species) that we used to define dot sizes in Figures 3, 4, and 5. (B) Excluded taxa. Families or subfamilies that were immediately omitted because of too few (i.e., <5) species (I) or secondarily omitted when we adopted a lower-level analysis (II) (see text for details).

\begin{tabular}{|c|c|c|c|c|c|c|}
\hline \multicolumn{7}{|c|}{ A. } \\
\hline Taxon & $\begin{array}{l}\text { Rank } \\
\text { number }\end{array}$ & $\begin{array}{l}\text { Proportion } \\
\text { exposed } \\
\text { feeding }\end{array}$ & $\begin{array}{l}\text { Proportion } \\
\text { woody } \\
\text { host plants }\end{array}$ & $\begin{array}{l}\text { Proportion } \\
\text { generalist } \\
\text { feeding }\end{array}$ & $\begin{array}{l}\text { Proportion } \\
\text { Eurosids } \\
\text { I host plants }\end{array}$ & $\begin{array}{l}\text { Sample } \\
\text { size } \\
\text { category } \\
\end{array}$ \\
\hline Eriocraniidae & 1 & 0 & 1 & 0.125 & 1 & 1 \\
\hline Hepialidae & 2 & 0.8 & 0 & 0.8 & 0 & 1 \\
\hline Stigmella & 3 & 0 & 0.911 & 0.129 & 0.953 & 4 \\
\hline Trifurcula & 4 & 0 & 0.429 & 0 & 0.857 & 1 \\
\hline Ectoedemia & 5 & 0 & 0.864 & 0.136 & 0.826 & 3 \\
\hline Heliozelidae & 6 & 0 & 1 & 0 & 0.6 & 1 \\
\hline Adelidae & 7 & 0.821 & 0.143 & 0.6 & 0.278 & 2 \\
\hline Prodoxidae & 8 & 0 & 1 & 0 & 0.8 & 1 \\
\hline Incurvariidae & 9 & 0.4 & 0.5 & 0.8 & 0.867 & 1 \\
\hline Tischeriidae & 10 & 0 & 0.917 & 0.5 & 1 & 1 \\
\hline Psychidae & 11 & 1 & 0 & 1 & 0 & 2 \\
\hline Tineidae & 12 & 0.462 & 0 & 0.857 & - & 3 \\
\hline Bucculatricidae & 13 & 0.5 & 0.636 & 0.364 & 0.545 & 2 \\
\hline Gracillariinae & 14 & 0.424 & 0.779 & 0.206 & 0.697 & 3 \\
\hline Lithocolletinae & 15 & 0 & 0.945 & 0.182 & 0.836 & 4 \\
\hline Yponomeutinae & 16 & 0.544 & 0.826 & 0.174 & 0.726 & 3 \\
\hline Argyresthiinae & 17 & 0.023 & 1 & 0.292 & 0.604 & 3 \\
\hline Ypsolophidae & 18 & 1 & 1 & 0.385 & 0.769 & 2 \\
\hline Plutellidae & 19 & 1 & 0 & 0.5 & 0 & 1 \\
\hline Acrolepiidae & 20 & 0.4 & 0 & 0.2 & 0 & 1 \\
\hline Glyphipterigidae & 21 & 0 & 0 & 0.143 & 0 & 1 \\
\hline Lyonetiidae & 22 & 0 & 0.7 & 0.4 & 1 & 1 \\
\hline Ethmiinae & 23 & 1 & 0 & 0.333 & 0 & 1 \\
\hline Agonopterix & 24 & 0.896 & 0.241 & 0.448 & 0.276 & 3 \\
\hline Depressaria & 25 & 0.836 & 0 & 0.857 & 0 & 2 \\
\hline Elachistinae & 26 & 0 & 0.023 & 0.476 & 0.024 & 4 \\
\hline Agonoxeninae & 27 & 0 & 1 & 0 & 0.833 & 1 \\
\hline Scythridinae & 28 & 1 & 0.417 & 0.364 & 0.153 & 2 \\
\hline Oecophoridae & 29 & 0.267 & 0.179 & 0.714 & 0.5 & 2 \\
\hline Coleophorinae & 30 & 0.509 & 0.373 & 0.377 & 0.348 & 5 \\
\hline Momphinae & 31 & 0.143 & 0.071 & 0.071 & 0 & 2 \\
\hline Amphisbatidae & 32 & 1 & 0.3 & 0.8 & 0.75 & 1 \\
\hline Cosmopterigidae & 33 & 0 & 0.273 & 0.3 & 0.7 & 1 \\
\hline Gelechiinae & 34 & 0.597 & 0.345 & 0.355 & 0.39 & 5 \\
\hline Dichomeridinae & 35 & 0.813 & 0.556 & 0.333 & 0.25 & 1 \\
\hline Zygaenidae & 36 & 0.864 & 0.182 & 0.273 & 0.545 & 2 \\
\hline Sesiidae & 37 & 0.036 & 0.786 & 0.4 & 0.733 & 2 \\
\hline Choreutidae & 38 & 1 & 0.333 & 0.333 & 0.5 & 1 \\
\hline Tortricini & 39 & 0.95 & 0.839 & 0.71 & 0.711 & 3 \\
\hline Cochylini & 40 & 0.215 & 0.136 & 0.468 & 0.09 & 4 \\
\hline Cnephasiini & 41 & 0.893 & 0.133 & 1 & 0.313 & 2 \\
\hline Archipini & 42 & 0.935 & 0.725 & 0.889 & 0.333 & 3 \\
\hline Endothenia & 43 & 0.063 & 0 & 0.375 & 0 & 1 \\
\hline Apotomis & 44 & 1 & 1 & 0 & 0.393 & 1 \\
\hline Hedya & 45 & 1 & 1 & 1 & 1 & 1 \\
\hline
\end{tabular}


Appendix. Continued.

\begin{tabular}{|c|c|c|c|c|c|c|}
\hline Taxon & $\begin{array}{l}\text { Rank } \\
\text { number }\end{array}$ & $\begin{array}{l}\text { Proportion } \\
\text { exposed } \\
\text { feeding }\end{array}$ & $\begin{array}{l}\text { Proportion } \\
\text { woody } \\
\text { host plants }\end{array}$ & $\begin{array}{l}\text { Proportion } \\
\text { generalist } \\
\text { feeding }\end{array}$ & $\begin{array}{l}\text { Proportion } \\
\text { Eurosids } \\
\text { I host plants }\end{array}$ & $\begin{array}{l}\text { Sample } \\
\text { size } \\
\text { category }\end{array}$ \\
\hline Celypha & 46 & 0.75 & 0.2 & 0.6 & 0 & 1 \\
\hline Phiaris & 47 & 1 & 0.6 & 0.8 & 0 & 1 \\
\hline Lobesia & 48 & 0.8 & 0.2 & 0.6 & 0.5 & 1 \\
\hline Ancylis & 49 & 1 & 0.824 & 0.647 & 0.824 & 2 \\
\hline Epinotia & 50 & 0.607 & 0.929 & 0.462 & 0.667 & 3 \\
\hline Gypsonoma & 51 & 0.5 & 1 & 0.333 & 0.531 & 1 \\
\hline Epiblema & 52 & 0.433 & 0.467 & 0.267 & 0.467 & 2 \\
\hline Eucosma & 53 & 0.286 & 0.071 & 0.214 & 0 & 2 \\
\hline Pammene & 54 & 0.357 & 1 & 0.263 & 0.625 & 2 \\
\hline Cydia & 55 & 0.172 & 0.652 & 0.454 & 0.697 & 3 \\
\hline Dichrorampha & 56 & 0.033 & 0 & 0.467 & 0 & 2 \\
\hline Epermeniidae & 57 & 0.75 & 0 & 0.875 & 0 & 1 \\
\hline Pterophoridae & 58 & 0.689 & 0.024 & 0.416 & 0.054 & 4 \\
\hline Scopariinae & 59 & 1 & 0 & 0.917 & 0 & 2 \\
\hline Crambinae & 60 & 0.895 & 0 & 0.844 & 0 & 3 \\
\hline Nymphulinae & 61 & 0.766 & 0 & 0.818 & 0 & 1 \\
\hline Pyraustinae & 62 & 0.593 & 0.146 & 0.643 & 0.149 & 3 \\
\hline Galleriinae & 63 & 1 & 0.2 & 0.333 & - & 1 \\
\hline Pyralinae & 64 & 1 & 0.028 & 0.091 & 0 & 2 \\
\hline Phycitinae & 65 & 0.648 & 0.474 & 0.5 & 0.417 & 4 \\
\hline Lasiocampidae & 66 & 1 & 0.576 & 1 & 0.583 & 2 \\
\hline Sphingidae & 67 & 1 & 0.35 & 0.8 & 0.184 & 2 \\
\hline Hesperiidae & 68 & 1 & 0 & 0.556 & 0.222 & 1 \\
\hline Pierinae & 69 & 1 & 0.167 & 1 & 0.167 & 1 \\
\hline Satyrinae & 70 & 1 & 0 & 0.833 & 0 & 2 \\
\hline Heliconiinae & 71 & 1 & 0 & 0.2 & 0.944 & 1 \\
\hline Nymphalinae & 72 & 1 & 0.15 & 0.7 & 0.729 & 1 \\
\hline Lycaenidae & 73 & 0.706 & 0.306 & 0.353 & 0.563 & 2 \\
\hline Thyatirinae & 74 & 1 & 1 & 0.222 & 1 & 1 \\
\hline Drepaninae & 75 & 1 & 1 & 0.5 & 0.833 & 1 \\
\hline Ennominae & 76 & 1 & 0.835 & 0.827 & 0.473 & 4 \\
\hline Geometrinae & 77 & 1 & 0.6 & 0.6 & 0.63 & 1 \\
\hline Cyclophora & 78 & 1 & 1 & 0 & 0.857 & 1 \\
\hline Scopula & 79 & 1 & 0.136 & 0.909 & 0.1 & 2 \\
\hline Idaea & 80 & 1 & 0.139 & 0.833 & 0.059 & 2 \\
\hline Larentiinae & 81 & 0.927 & 0.511 & 0.457 & 0.323 & 5 \\
\hline Notodontidae & 82 & 1 & 1 & 0.636 & 0.9 & 3 \\
\hline Nolidae & 83 & 1 & 0.889 & 0.444 & 0.963 & 1 \\
\hline Catocalinae & 84 & 1 & 0.437 & 0.5 & 0.8 & 2 \\
\hline Hypeninae (incl. Hermiinae) & 85 & 1 & 0.448 & 0.583 & 0.556 & 2 \\
\hline Lithosiinae & 86 & 1 & 0 & 1 & 0 & 2 \\
\hline Arctiinae & 87 & 1 & 0.179 & 0.923 & 0.297 & 2 \\
\hline Lymantriidae & 88 & 1 & 1 & 1 & 0.719 & 1 \\
\hline Eustrotiinae & 89 & 0.75 & 0 & 0.833 & 0 & 1 \\
\hline Plusiinae & 90 & 1 & 0.133 & 0.8 & 0.385 & 2 \\
\hline Acronictinae & 91 & 1 & 0.872 & 0.923 & 0.683 & 2 \\
\hline Heliothinae & 92 & 1 & 0.1 & 0.833 & 0.35 & 1 \\
\hline Cuculliinae & 93 & 1 & 0 & 0.444 & 0 & 1 \\
\hline Hadeninae & 94 & 0.731 & 0.289 & 0.713 & 0.214 & 4 \\
\hline Noctuinae & 95 & 0.704 & 0.289 & 0.961 & 0.29 & 4 \\
\hline
\end{tabular}


Appendix. Continued.

\begin{tabular}{|c|c|c|c|c|c|c|}
\hline Grade & Family & Subfamily & Tribe & Genus & $\begin{array}{l}\text { Number of } \\
\text { species }\end{array}$ & $\begin{array}{l}\text { Stage of } \\
\text { exclusion }\end{array}$ \\
\hline Lower Lepidoptera & Micropterigidae & & & & 5 & I \\
\hline Lower Lepidoptera & Opostegidae & & & & 4 & I \\
\hline Lower Lepidoptera & Nepticulidae & & & $\begin{array}{l}\text { Enteucha and } \\
\text { Bohemannia }\end{array}$ & 4 & II \\
\hline Lower Ditrysia & Psychidae & Oiketicinae & & & 3 & I \\
\hline Lower Ditrysia & Ypsolophidae & Ochsenheimeriinae & & & 3 & I \\
\hline Lower Ditrysia & Gracillariidae & Phyllocnistinae & & & 3 & I \\
\hline Lower Ditrysia & Douglasiidae & & & & 2 & I \\
\hline Lower Ditrysia & Heliodinidae & & & & 1 & I \\
\hline Lower Ditrysia & Glyphipterigidae & Orthotaeliinae & & & 1 & I \\
\hline Lower Ditrysia & Elachistidae & Depressariinae & & $\begin{array}{l}\text { Other genera than } \\
\text { Depressaria and } \\
\text { Agonopterix }\end{array}$ & 9 & II \\
\hline Lower Ditrysia & Chimabachidae & & & & 3 & I \\
\hline Lower Ditrysia & Autostichidae & Symmocinae & & & 4 & I \\
\hline Lower Ditrysia & Coleophoridae & Blastobasinae & & & 2 & I \\
\hline Lower Ditrysia & Batrachedridae & & & & 2 & I \\
\hline Lower Ditrysia & Gelechiidae & $\begin{array}{l}\text { Other than Gelechiinae } \\
\text { and Dichomeriinae }\end{array}$ & & & 4 & II \\
\hline Lower Apoditrysia & Cossidae & & & & 4 & I \\
\hline Lower Apoditrysia & Limacodidae & & & & 2 & I \\
\hline Lower Apoditrysia & Schreckensteiniidae & & & & 1 & I \\
\hline Lower Apoditrysia & Alucitidae & & & & 1 & I \\
\hline Lower Apoditrysia & Tortricidae & Chlidanotinae & & & 2 & I \\
\hline Lower Apoditrysia & Tortricidae & Tortricinae & Sparganothini & & 1 & II \\
\hline Lower Apoditrysia & Tortricidae & Tortricinae & Euliini & & 1 & II \\
\hline Lower Apoditrysia & Tortricidae & Olethreutinae & & $\begin{array}{l}\text { Other than selected } \\
14 \text { genera }\end{array}$ & 46 & II \\
\hline Lower Apoditrysia & Crambidae & Schoenobiinae & & & 3 & I \\
\hline Lower Apoditrysia & Crambidae & Evergestinae & & & 4 & I \\
\hline Lower Apoditrysia & Crambidae & Odontiinae & & & 2 & I \\
\hline Lower Apoditrysia & Crambidae & Glaphyriinae & & & 1 & I \\
\hline Macrolepidoptera & Nymphalidae & Limenitinae & & & 1 & I \\
\hline Macrolepidoptera & Nymphalidae & Apaturinae & & & 1 & I \\
\hline Macrolepidoptera & Nymphalidae & Danainae & & & 1 & I \\
\hline Macrolepidoptera & Pieridae & Dismorphiinae & & & 1 & I \\
\hline Macrolepidoptera & Saturniidae & & & & 2 & I \\
\hline Macrolepidoptera & Endromidae & & & & 1 & I \\
\hline Macrolepidoptera & Geometridae & Archiearinae & & & 1 & I \\
\hline Macrolepidoptera & Geometridae & Alsophilinae & & & 1 & I \\
\hline Macrolepidoptera & Geometridae & Sterrhinae & & $\begin{array}{l}\text { Timandra and } \\
\text { Rhodometra }\end{array}$ & 2 & II \\
\hline Macrolepidoptera & Arctiidae & Syntominae & & & 2 & II \\
\hline Macrolepidoptera & Arctiidae & Arctiinae & Euchromiini & & 4 & II \\
\hline Macrolepidoptera & Noctuidae & Bilobinae & & & 1 & II \\
\hline Macrolepidoptera & Noctuidae & Glottulinae & & & 1 & II \\
\hline Macrolepidoptera & Noctuidae & Psaphidinae & & & 2 & II \\
\hline Macrolepidoptera & Noctuidae & Bryophilinae & & & 4 & II \\
\hline Macrolepidoptera & Noctuidae & Condicinae & & & 1 & II \\
\hline Macrolepidoptera & Noctuidae & Stiriinae & & & 1 & II \\
\hline Macrolepidoptera & Noctuidae & Amphipyrinae & & & 3 & II \\
\hline Macrolepidoptera & Noctuidae & Acontiinae & & & 4 & II \\
\hline Macrolepidoptera & Pantheidae & & & & 3 & I \\
\hline Total & & & & & 152 & \\
\hline
\end{tabular}

